\title{
$\mathrm{P}$ \\ езультаты анализа деятельности медицинских организаций дерматовенерологического профиля в Российской Федерации за 2012 год
}

\author{
А.А. Кубанова, А.А. Кубанов, Л.Е. Мелехина, Е.В. Богданова, М.М. Бутарева
}

ФГБУ «Государственный научный центр дерматовенерологии и косметологии» Минздрава России 107076, Москва, ул. Короленко, д. 3, стр. 6

Анализируются показатели работы медицинских организаций дерматовенерологического профилл, оценивается заболеваемость инфрекциями, передаваемыми половым путем, и дерматозами, эсффективность организационнопросиилактических мероприятий по предупреждению распространения заболеваний и рациональность использования коечного фронда, в том числе дневного стационара, как структурного подразделения.

Ключевые слова: ресурсы медицинских организаций, стандарты оказания медицинской помощи, статистическая информация, работа койки дерматовенерологического профиля.

Контактная информация: butareva@cnikvi.ru. Вестник дерматологии и венерологии 2013; (5): 21_39.

\section{Results of the analysis of dermatovenereologic healthcare organizations activity in Russian Federation in 2012}

\author{
A.A. Kubanova, A.A. Kubanov, L.E. Melekhina, E.V. Bogdanova, M.M. Butareva
}

State Research Center of Dermatovenereology and Cosmetology, Ministry of Healthcare of the Russian Federation Korolenko str., 3, bldg 6, Moscow, 107076, Russia

\footnotetext{
The paper presents the analysis of the work of dermatovenereologic healthcare organizations in Russian Federation, rationality of hospital bed and day hospital bed usage, incidence and effectiveness of preventive control of sexually transmitted infections and skin disorders.
}

Key words: healthcare organizations resources, medical care standards, statistical information, bed rates. 
Согласно стратегии национальной безопасности Российской Федерации до 2020 года, утвержденной Указом Президента Российской Федерации от 12.05.2009 № 537, а также государственной программе «Развитие здравоохранения», утвержденной распоряжением Правительства РФ от 24.12.2012 № 2511-р, государственная политика России в сорере здравоохранения и здоровья нации направлена на профилактику, стабилизацию заболеваемости социально значимыми заболеваниями и на формирование нормативно-правовой базы с целью повышения доступности и качества, а также реализации гарантий обеспечения населения медицинской помощью $[1,2]$.

Для решения задач национальной безопасности в сорере здравоохранения и здоровья нации:

шормируются национальные программы (проекты) по лечению социально значимых заболеваний с разработкой единых общероссийских подходов к диагностике, лечению и реабилитации пациентов;

- развиваются системы управления качеством и доступностью медицинской помощи, подготовкой специалистов здравоохранения;

- разрабатываются и реализуются перспективные технологии и национальные программы государственной поддержки профилактики заболеваний для ликвидации предпосылок эпидемий.

Нормативные документы, регламентирующие деятельность медицинских организаций дерматовенерологического профиля в РФ в настоящее время, включают в себя:

Федеральный закон от 21.11.2011 № 323-Ф3 (ред. от 25.06.2012) «Об основах охраны здоровья граждан в Российской Федерации»;

- Федеральный закон от 29.11.2010 № 326-Ф3 «Об обязательном медицинском страховании в Российской Федерации";

П Постановление Правительства РФ от 04.10.2012 № 1006 «Об утверждении Правил предоставления медицинскими организациями платных медицинских услуг»;

- Постановление Правительства РФ от 16.04.2012 № 291 «О лицензировании медицинской деятельности (за исключением указанной деятельности, осуществляемой медицинскими организациями и другими организациями, входящими в частную систему здравоохранения, на территории инновационного центра “Сколково» (в ред. постановлений Правительства РФ от 04.09.2012 № 882, от 17.01.2013 № 9, от 15.04.2013 № 342)»;

п Постановление Правительства РФ от 22.10.2012 № 1074 «О программе государственных гарантий бесплатного оказания гражданам медицинской помощи на 2013 год и на плановый период 2014 и 2015 годов»;

- Приказ Министерства здравоохранения России от 15.11.2012 № 924н «Об утверждении Порядка оказания медицинской помощи населению по профилю «дерматовенерология» (зарегистрирован в Минюсте России 21.12.2012 № 26302);

- Приказ Министерства здравоохранения и социального развития РФ от 12.04.2011 № $302 \mathrm{H}$ «Об утверждении перечней вредных и (или) опасных производственных фракторов и работ, при выполнении которых проводятся обязательные предварительные и периодические медицинские осмотры (обследования), и Порядка проведения обязательных предварительных и периодических медицинских осмотров (обследований) работников, занятых на тяжелых работах и на работах с вредными и (или) опасными условиями труда»*;

- Стандарты оказания медицинской помощи по профилю «дерматовенерология», утвержденные Министерством здравоохранения Российской Федерации.

Анализ интенсивных показателей деятельности медицинских организаций позволяет оценить эффективность выполнения объемов медицинской помощи, рациональное и целевое использование коечного фонда, обеспеченность населения койками и медицинскими кадрами, полноценность охвата больных диспансерным наблюдением, уровень госпитализации населения и ряд других показателей.

В 2012 году в Российской Федерации медицинское обслуживание больных дерматовенерологического профриля осуществлялось 165 диспансерами, 7 центрами специализированной помощи, а также в клиниках вузов, НИИ, городских, районных и областных больницах (рис. 1). В результате реорганизации кожно-венерологических диспансеров к 2012 году на их базе было создано семь центров специализированной помощи, что позволило увеличить мощность медицинских организаций и расширить возможности оказания медицинской помощи населению. В то же время в формах федерального статистического наблюдения указанные центры не были выделены в отдельную позицию, поэтому показатели их деятельности были отнесены в раздел «Прочие больничные организации», и в связи с этим объективно проанализировать качество оказания медицинской помощи не представляется возможным.

\footnotetext{
* Проект Приказа Министерства здравоохранения Российской Федерации от 15 мая 2013 г. "Об утверждении Перечня производственных факторов, Перечня отдельных видов работ, при выполнении которых проводятся обязательные предварительные и периодические медицинские осмотры, Порядка проведения обязательных предварительных (при поступлении на работу) и периодических медицинских осмотров (обследований) работников, занятых на отдельных видах работ, тяжелых работах и на работах с вредными и (или) опасными условиями труда", регламентирующий проведение профилактических осмотров определенных категорий населения в Российской Федерации, направлен на усиление профилактических осмотров по выявлению больных ИППП среди декретированного контингента путем увеличения кратности обследований.
} 


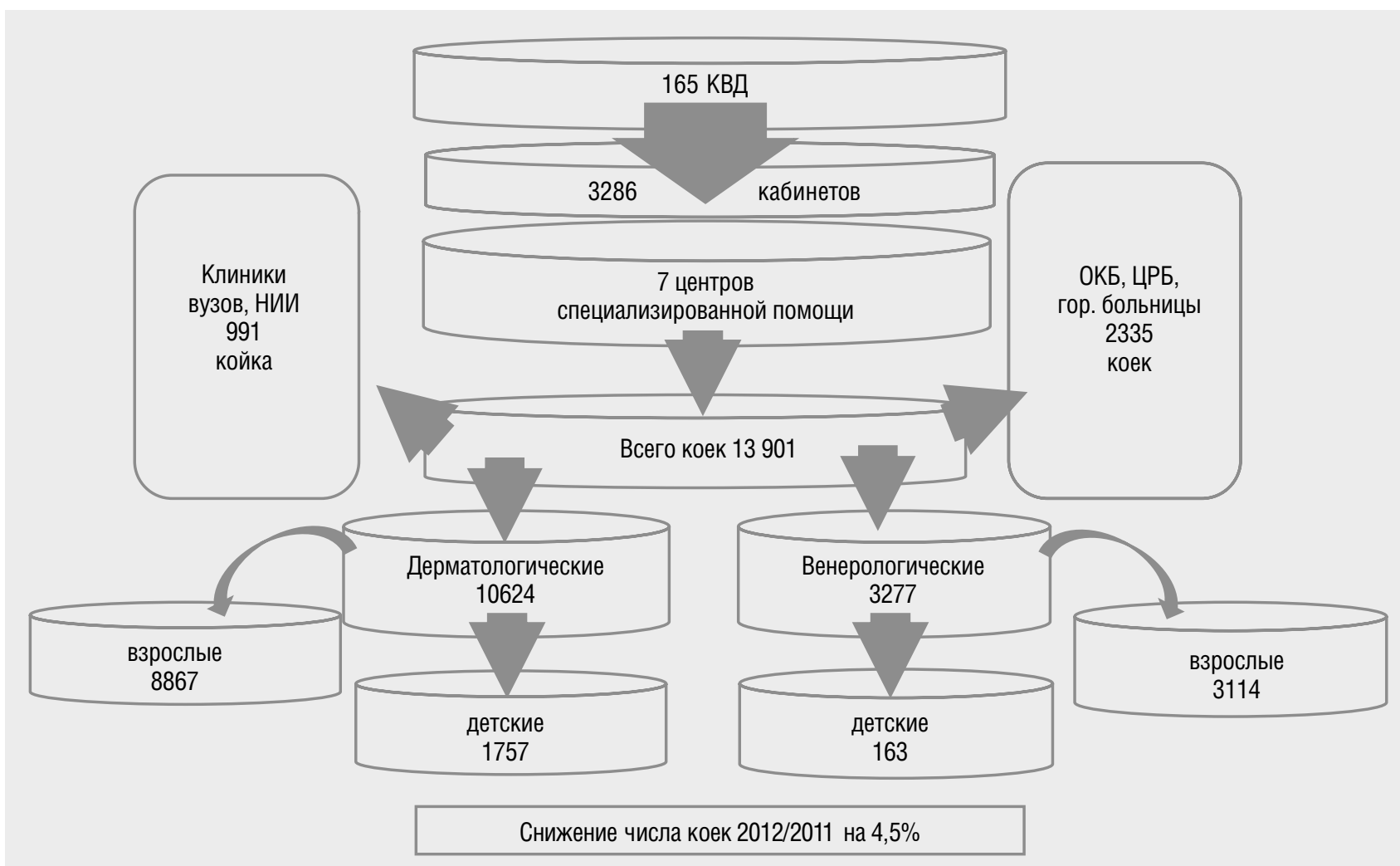

Рис. 1. Ресурсы медицинских организаций дерматовенерологического профиля в 2012 году

Количество кожно-венерологических диспансеров, применяющих в своей работе медико-экономические стандарты, увеличилось по сравнению с 2011 годом с 45 до $51 \%$.

Количество кожно-венерологических учреждений, в которых оплата медицинской помощи осуществляется по результатам их деятельности, снизилось с 43,7 до 28,4\%, а доля кожно-венерологических диспансеров, переведенных на оплату труда, ориентированную на результат, продолжает увеличиваться с 90,8\% в 2011 году до 94,5\% в 2012 году. В два раза увеличилось количество КВД, перешедших на одноканальное финансирование.

В 2012 году стандарты медицинской помощи в своей лечебно-диагностической деятельности использовали 70\% медицинских организаций дерматовенерологического профиля (КВД). С 1 января 2013 года во исполнение Федерального закона от 21.11.2011 № 323-Ф3 «Об основах охраны здоровья граждан в Российской Федерации» пункта 1 статьи 37 медицинская помощь во всех медицинских организациях на территории Российской Федерации организуется и оказывается в соответствии с порядками оказания медицинской помощи, а также на основе стандартов медицинской помощи.
В 2012 году 1,8\% медицинских организаций дерматовенерологического профиля предоставили пациентам высокотехнологичную специализированную медицинскую помощь по профилю «дерматовенерология» в соответствии с Порядком направления граждан Российской Федерации для оказания данного вида медицинской помощи, утвержденным Приказом Минздравсоцразвития РФ от 28.12.2011 № 1689н (рис. 2).

Согласно Федеральному закону от 21.11.2011 № 323-Ф3 (ред. от 25.06.2012) “Об основах охраны здоровья граждан в Российской Федерации» применение Порядков и стандартов оказания медицинской помощи является одним из условий, гарантирующих ее доступность и качество. В соответствии с этим Министерство здравоохранения Российской Федерации поручило главным специалистам возглавить работу профильных комиссий по актуализации Порядка и стандартов оказания медицинской помощи по профрилю «дерматовенерология». Специалистами профильной комиссии по дерматовенерологии был подготовлен 161 стандарт оказания медицинской помощи, в том числе 89 - больным болезнями кожи и подкожной клетчатки; 25 - урогенитальными инфекциями и 

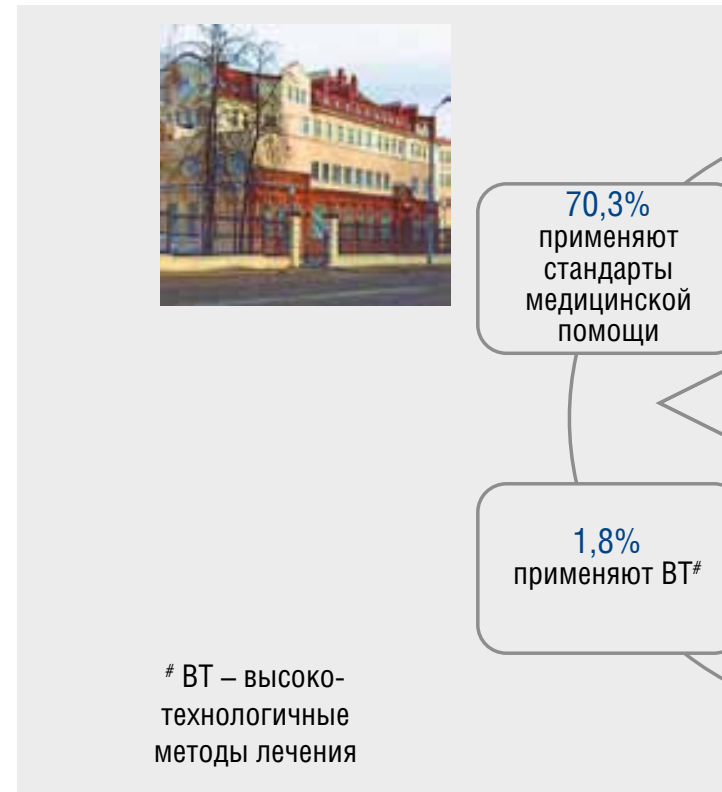

(1)

технологичные методы лечения

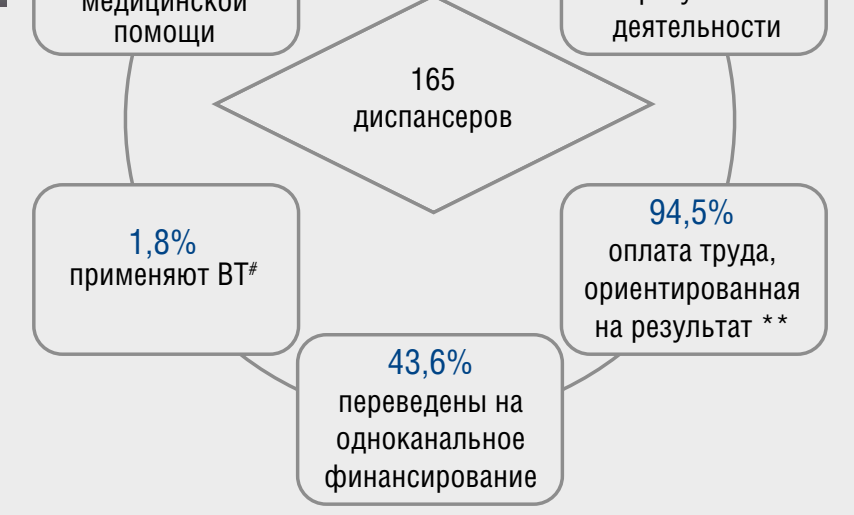

* МЭС - медико-

экономические

стандарты

Рис. 2. Количество организаций по эфффективности использования усовершенствованных форм оказания медицинской помощи [2012 г.]

47 - больным сифилисом. В соответствии с поручением Минздрава Российской Федерации специалистами профильной комиссии в 2013 году проводится работа по подготовке фредеральных клинических рекомендаций по профилю «дерматовенерология».

В Российской Федерации бесплатная медицинская помощь оказывается в соответствии с Программой государственных гарантий бесплатного оказания гражданам медицинской помощи, утвержденной Постановлением Правительства РФ от 22.10.2012 № 1074. В Программе государственных гарантий указываются виды, формы и условия оказания данной медицинской помощи, перечень заболеваний и состояний, категории граждан и средние нормативы объема бесплатной медицинской помощи. Содержание и объемы гарантированной государством медицинской помощи населению определяются базовой программой обязательного медицинского страхования (ОМС), являющейся частью программы государственных гарантий бесплатного оказания гражданам медицинской помощи. Кроме того, оплата медицинских услуг возможна за счет личных средств граждан, средств юридических лиц и иных средств, в том числе договоров добровольного медицинского страхования (ДМС). В соответствии с Правилами предоставления медицинскими организациями платных медицинских услуг, утвержденными Постановлением Правительства РФ от 04.10.2012 № 1006, медицинские организации, участвующие в реализации программы, имеют право предоставлять платные медицинские услуги на договорной основе сверх нормативного объема медицинской помощи, предусмотренного программой, в том числе на анонимной основе.

Обеспеченность населения материально-техническими и кадровыми ресурсами в соответствии с утвержденными нормативами позволит гражданам Российской Федерации получать медицинскую помощь в объеме, полностью соответствующем современным требованиям и Программе государственных гарантий бесплатного оказания медицинской помощи [3].

Обеспеченность населения квалифицированным медицинским персоналом является одним из условий, гарантирующим доступность и надлежащее качество оказания медицинской помощи. Показатель обеспеченности населения врачами-дерматовенерологами в целом по Российской Федерации увеличился в 2012 году на 14\%, составив 0,8 против 0,7 на 10 тысяч населения в 2011 году (рис. 3, 4).

Обеспеченность населения регионов Российской Федерации врачами-дерматовенерологами складывается неравномерно. Диапазон различия в кадровых ресурсах составляет от 0,29 до 1,6 на 10 тысяч населения. Центральный, Северо-Западный и Дальневосточный федеральные округа имеют показатель обеспеченности врачами-дерматовенерологами, превышающий среднероссийский показатель $(0,75$, 0,83 и 0,77 на 10 тысяч населения соответственно). Кадровый профицит возникает за счет крупных городов, где находится большое количество медицинских 


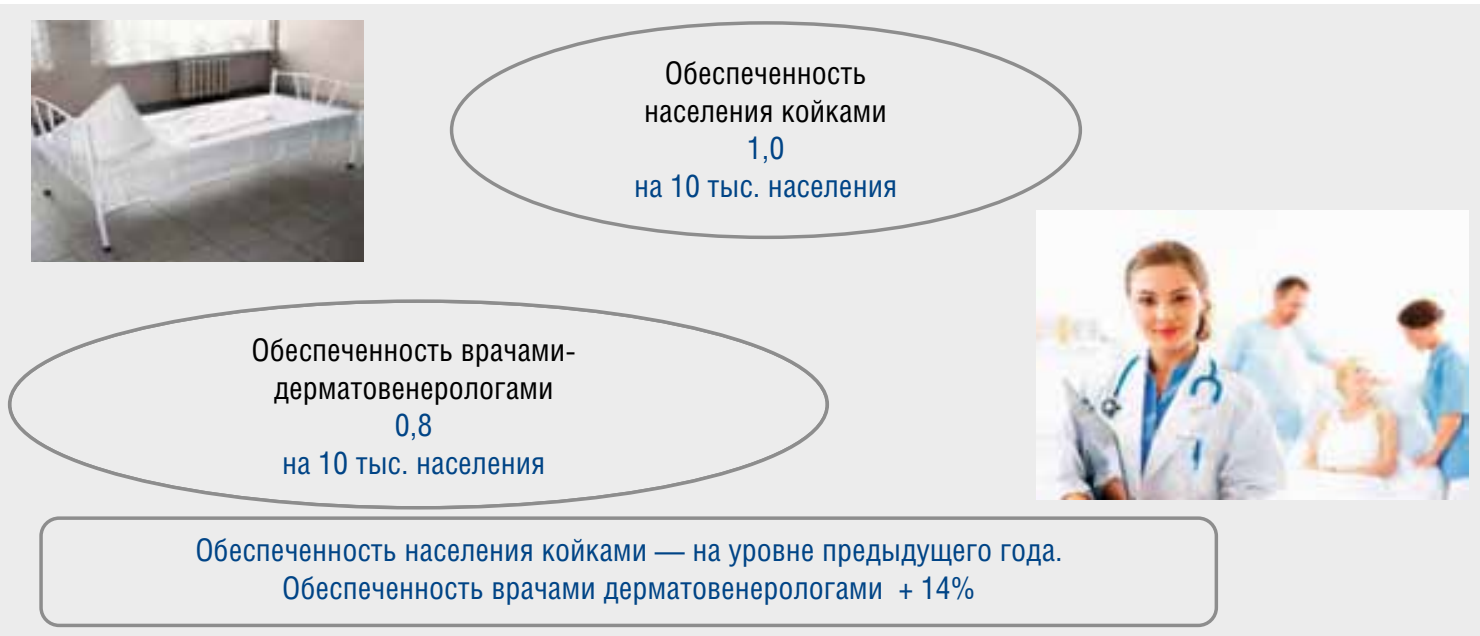

Рис. 3. Обеспеченность населения Российской Федерации специализированными койками и врачами по профилю «дерматовенерология» [2012 г.]

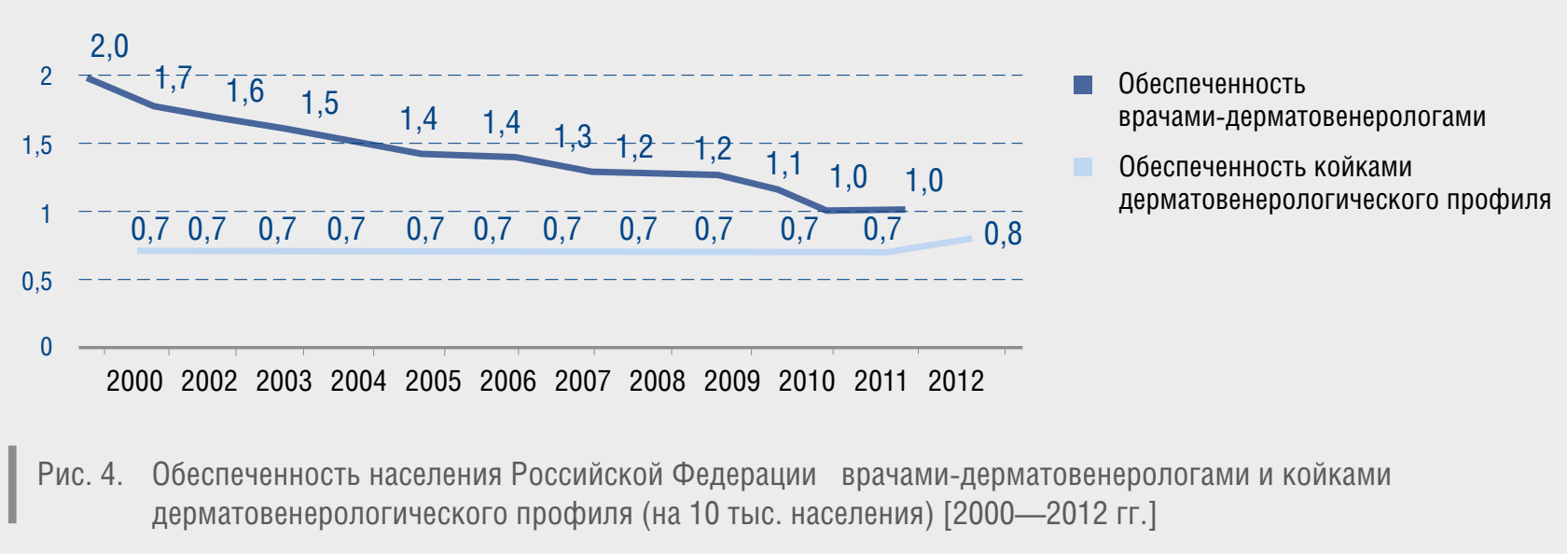

организаций, оказывающих специализированную медицинскую помощь (например, в Москве, Республике Северная Осетия - Алания, Астраханской области, Чукотском автономном округе и городе СанктПетербурге показатель превышает аналогичный среднероссийский практически в два раза: 1,04, 1,52, 1,58, 1,39 и 1,35 на 10 тысяч населения соответственно). Сосредоточение специалистов в региональных центрах и нехватка их в отдаленных сельских населенных пунктах снижает доступность медицинской помощи для сельского населения, среди которого заболеваемость выше, чем среди городского населения (35,8 и 32,1 на 100 тысяч соответствующего населения).
Низкий уровень обеспеченности врачами-дерматовенерологами в 2012 году отмечается в Тульской $(0,43)$, Тамбовской $(0,37)$, Вологодской $(0,42)$ областях, Карачаево-Черкесской $(0,29)$ и Чеченской $(0,34)$ республиках, где показатель почти в два раза ниже среднероссийского.

Основная доля врачей-дерматовенерологов, оказывающих специализированную медицинскую помощь населению, в 2012 году в Российской Федерации была занята на штатных должностях в поликлиниках медицинских организаций (85\%), и только 15\% врачей-дерматовенерологов работали в стационарах. Десицит врачей-дерматовенерологов в медицинских организациях согласно штатному расписанию состав- 
ляет в целом 8\%, из них 6\% - в стационарах и 9\%в поликлиниках.

Несмотря на продолжающееся сокращение коечного фонда (на 4,5\% по сравнению с 2011 годом), обеспеченность населения профильными койками сохраняется на уровне предыдущего года и составляет 1,0 на 10 тысяч населения (см. рис. 3, 4).

Среднее количество дней работы койки дерматовенерологического профиля в 2012 году составило 305 дней (2011 год - 302 дня). В последние 5 лет обозначилась тенденция интенсификации работы специализированной койки (увеличение на 3\% за 20072012 годы). Средняя длительность пребывания больного на койке дерматовенерологического профиля в целом по Российской Федерации составляет 16,6 дня, что обусловливает показатель оборота койки, равный 18,3 больных (рис. 5).

В условиях стационара в 2012 году получили лечение 254966 больных, страдающих болезнями кожи и инфекциями, передаваемыми половым путем (см. рис. 5). Специализированная медицинская помощь была оказана 223366 больным в возрасте 18 лет и старше (87,7\%) и 31600 детям 0-17 лет (12,3\%).

В 2012 году в Российской Федерации была развернута 13901 специализированная койка дерматовенерологического профиля, из них 10624 койки для больных болезнями кожи, в том числе 1757 для детей, и 3277 - для больных инфекциями, передаваемыми половым путем, из них 163 - для детей (см. рис. 5). На койках, развернутых для больных венерологического профиля, получили лечение по поводу инфекций, передаваемых половым путем, 51027 больных: 49108 - взрослых и 1894 - ребенка в возрасте 0-17 лет.

Количество дней занятости койки венерологического профриля в году в среднем составило 254,8 дня, что значительно ниже, чем работа койки дерматологического профиля $(319,6)$. Оборот койки венерологического профиля составил 15,7 больных, а дерматологического профриля - 19,2. Средняя длительность пребывания больного инфекциями, передаваемыми половым путем, на койке была равна 16,2 дня, заболеванием кожи - 16,6 (рис. 6).

Анализ показателей работы койки дерматовенерологического профиля выявил низкую загруженность коек для больных инфекциями, передаваемыми половым путем. Дальнейшее сокращение или перераспределение коечного фонда может происходить преимущественно за счет коек венерологического профиля, так как работа койки для больных болезнями кожи (дерматозами) соответствует нормативным показателям.

Внедрение современных методов исследования для диагностики, выявления и терапии больных ИППП позволило перевести социально адаптированную группу больных, согласно Приказу Минздрава России от 07.12.1993 № 286 «О совершенствовании контроля над заболеваниями, передаваемыми половым путем», со стационарного на амбулаторное лечение с целью рационального использования коечного фронда дерма-

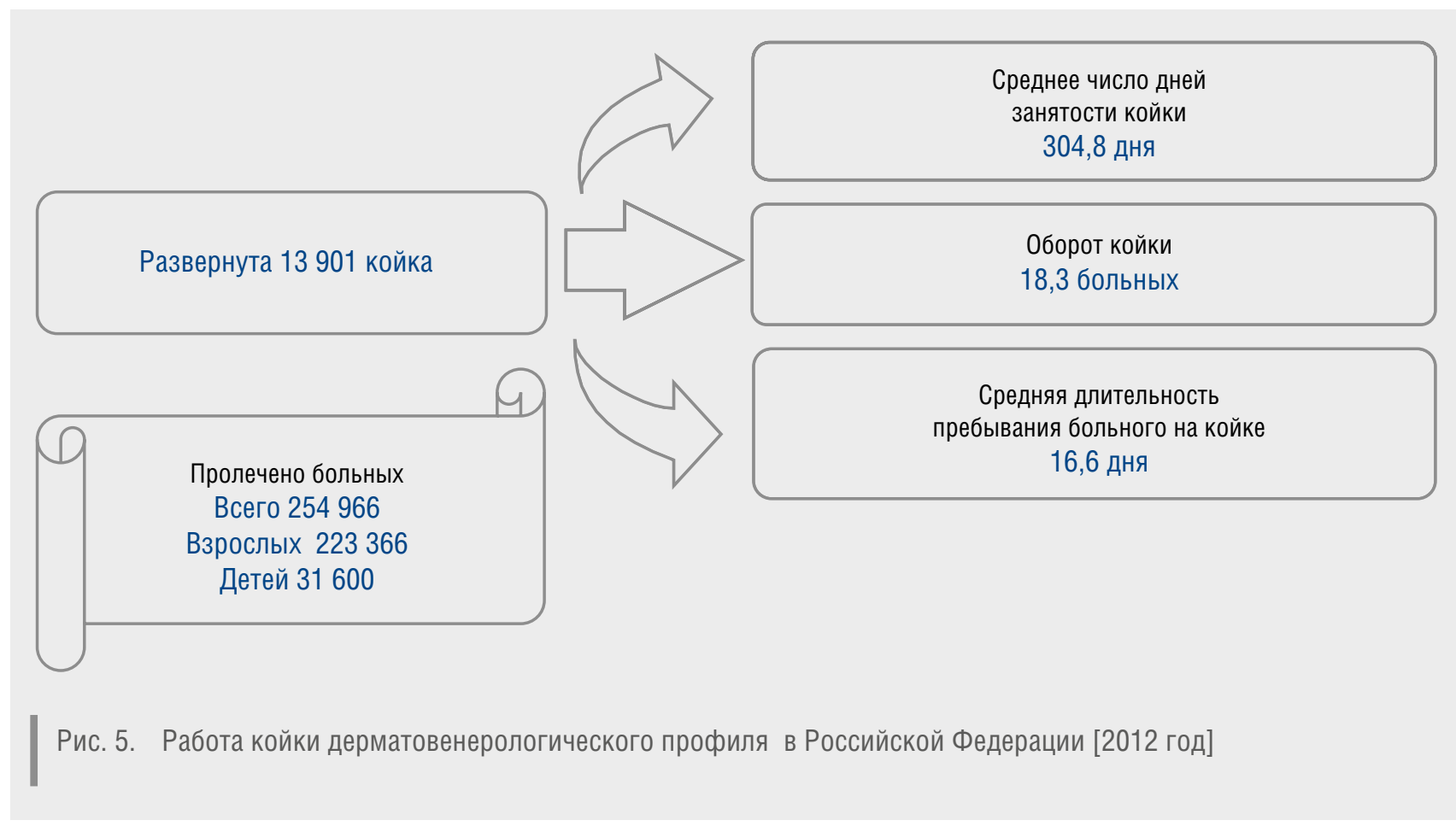




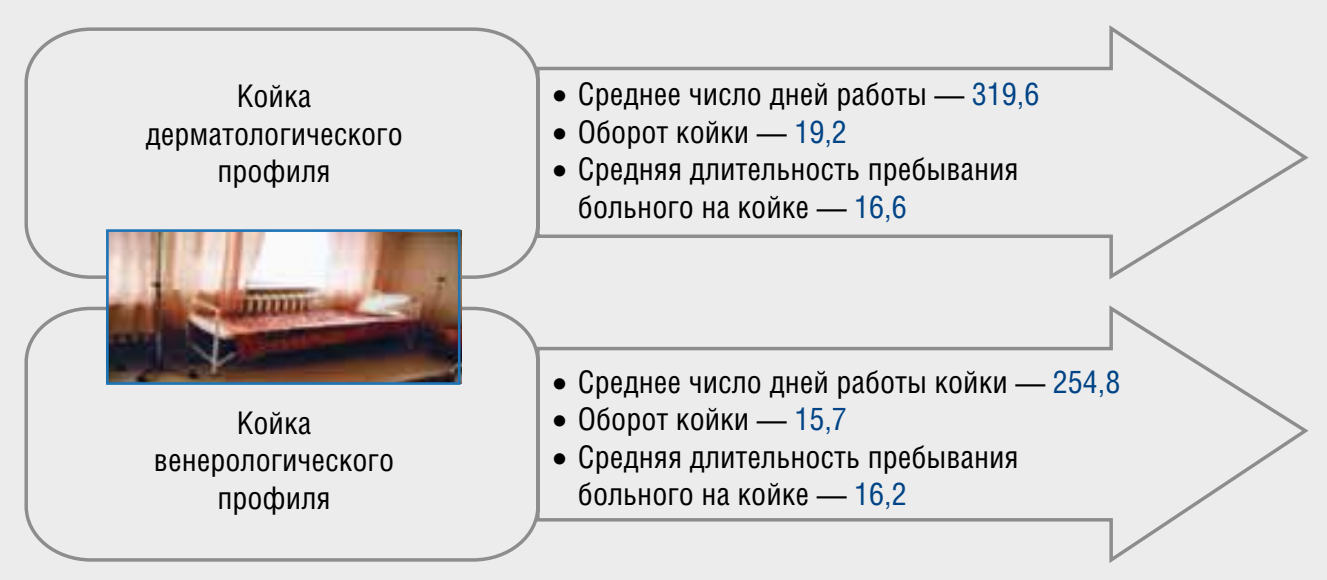

Рис. 6. Работа коек дерматологического и венерологического профиля в Российской Федерации в 2012 году

товенерологического профиля, сократив тем самым расходы бюджета. Наряду с этим, руководствуясь Порядком оказания медицинской помощи больным дерматовенерологического профиля, утвержденным Приказом Министерства здравоохранения Российской Федерации от 15.11.2012 № 924н, для определенной категории больных обследование и лечение необходимо проводить в условиях стационара.

В 2012 году в Российской Федерации из 165 кожно-венерологических диспансеров в 85 (51,5\%) были организованы дневные стационары больничных учреждений. Вследствие реструктуризации коечного фонда сократилось количество дневных стационаров больничных учреждений на $13,3 \%$ по сравнению с 2010 годом, однако доля кожно-венерологических диспансеров, имеющих дневные стационары больнич- ных учреждений, увеличилась с 44,7 до 51,5\%. Аналогичная тенденция наблюдается в КВД, имеющих дневные стационары амбулаторно-поликлинических учреждений, доля которых возросла с 33,8\% в 2010 году до 41,2\% в 2012 году (рис. 7).

В 2012 году в Российской Федерации было развернуто всего 2852 койки дерматовенерологического профиля (в том числе 208 для детей в возрасте 0-17 лет) при дневных стационарах больничных учреждений и 1767 мест при дневных стационарах амбулаторно-поликлинических учреждений (в том числе 126 для детей). Доля детских коек дерматовенерологического профиля в дневных стационарах при больничных учреждениях снизилась с 8,3\% в 2010 году до 7,9\% в 2012 году, однако доля мест для детей 0-17 лет в дневных стационарах амбулаторно-поликлиниче-

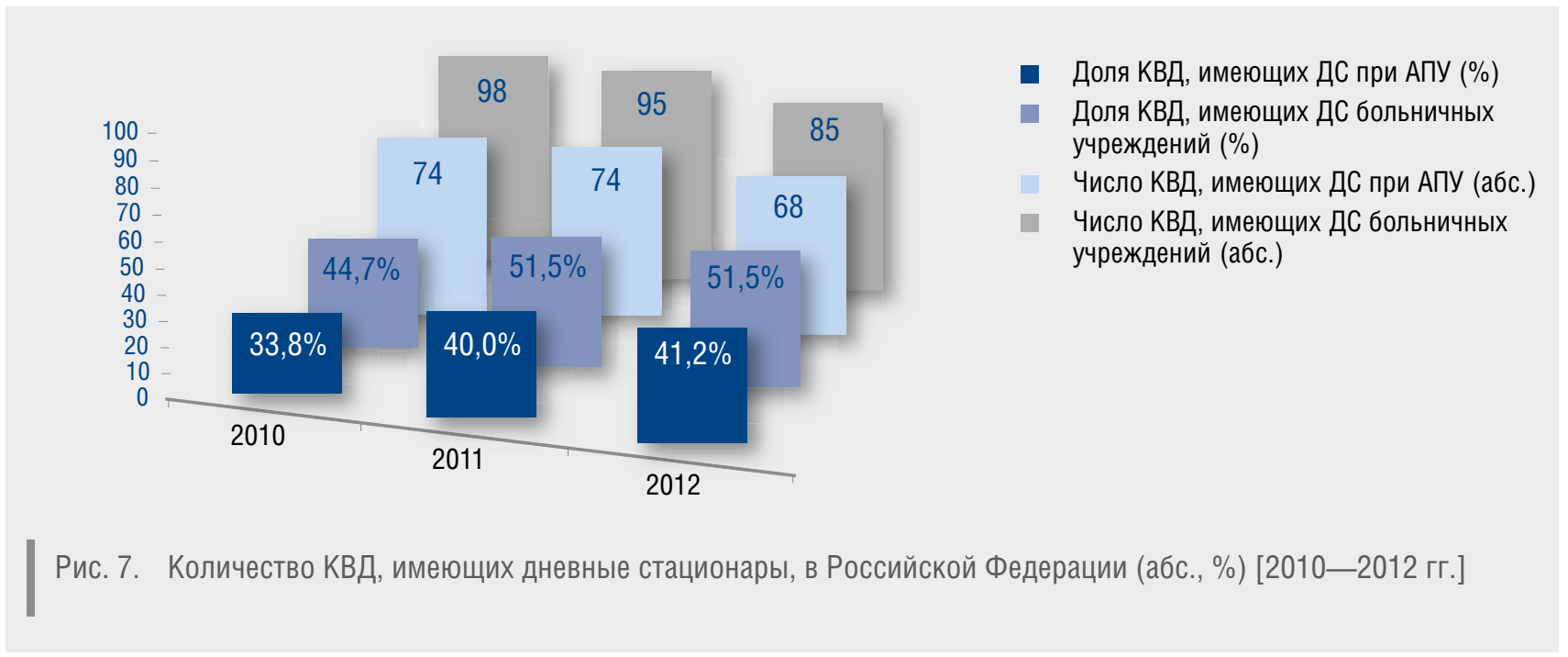


ских учреждений за тот же период возросла в полтора раза с 4,8 до $7,1 \%$.

Средняя занятость койки дневного стационара при больничном учреждении в 2012 году составила 300 дней (рис. 8), что несколько больше, чем в 2010 и 2011 годах (296 и 295 дней соответственно). Показатель средней занятости койки для взрослых составил 301 день и превысил аналогичный показатель работы койки для детей (297 дней). Средняя длительность пребывания больного дерматовенерологического профиля на койке дневного стационара больничного учреждения в 2012 году составила 14,7 дня, сохранив уровень двух предыдущих лет (14,6 дня). Средняя длительность пребывания больного на койке для детей (16,9 дня) превышает аналогичный показатель для взрослых на два дня (14,5 дня). Увеличилась средняя длительность лечения больных в дневных стационарах амбулаторно-поликлинических подразделений в 2012 году на 6,6\% по сравнению с 2010 годом (13,0 и 12,2 дня соответственно).

Проведение лабораторных методов исследования является неотъемлемой частью оказания медицинской помощи больным дерматовенерологического профиля. В 2012 году 957 медицинских организаций Российской Федерации имели в своей структуре микробиологическую (бактериологическую) лабораторию, из них 247 организаций имели централизованную микробиологическую лабораторию; иммунологическую (серологическую) лабораторию имели 580 медицинских организаций, из них 194 - централизованную; клинико-диагностические лаборатории имели 6643 медицинские организации, из них 348 - централизованные; в организационную структуру 174 меди- цинских организаций входила патоморфологическая лаборатория, в структуру 443 организаций - биохимическая лаборатория, в том числе в 74 организациях - централизованная.

Большое значение в установлении диагноза пациенту с подозрением на ИППП имеет лабораторное исследование. Современные методы лабораторных исследований обладают высокой клинической чувствительностью, специфичностью и воспроизводимостью, что гарантирует достоверность результатов.

Основные лабораторные методы, используемые в Российской Федерации при установлении диагноза инфекций, передаваемых половым путем, включают в себя иммунологические (серологические): РМП, РПР, РПГА, ИФА, РИФ, РИБТ, иммуноблот; бактериоскопический; бактериологический и молекулярно-биологический методы.

В Российской Федерации в 2012 году было зарегистрировано 48354 больных с вновь установленным диагнозом сифилиса. Для подтверждения диагноза больного в среднем обследовали с использованием 3 методов. Преобладающими серологическими методами исследования являются РМП, РПГА и ИФА. Они были применены для подтверждения диагноза у 82,5, 73,6 и 91,4\% больных с вновь установленным диагнозом сифилиса соответственно. Значительно реже используются такие методы, как РИФ, РПР, РИБТ и иммуноблот (31,6, 10,0, 3,7 и 4,1\% соответственно). Темнопольная микроскопия для подтверждения диагноза была проведена у 10,5\% больных. Медицинские организации дерматовенерологического профиля в своей лабораторной практике для подтверждения диагноза «сифилис» продолжают также использовать КСР, ку-

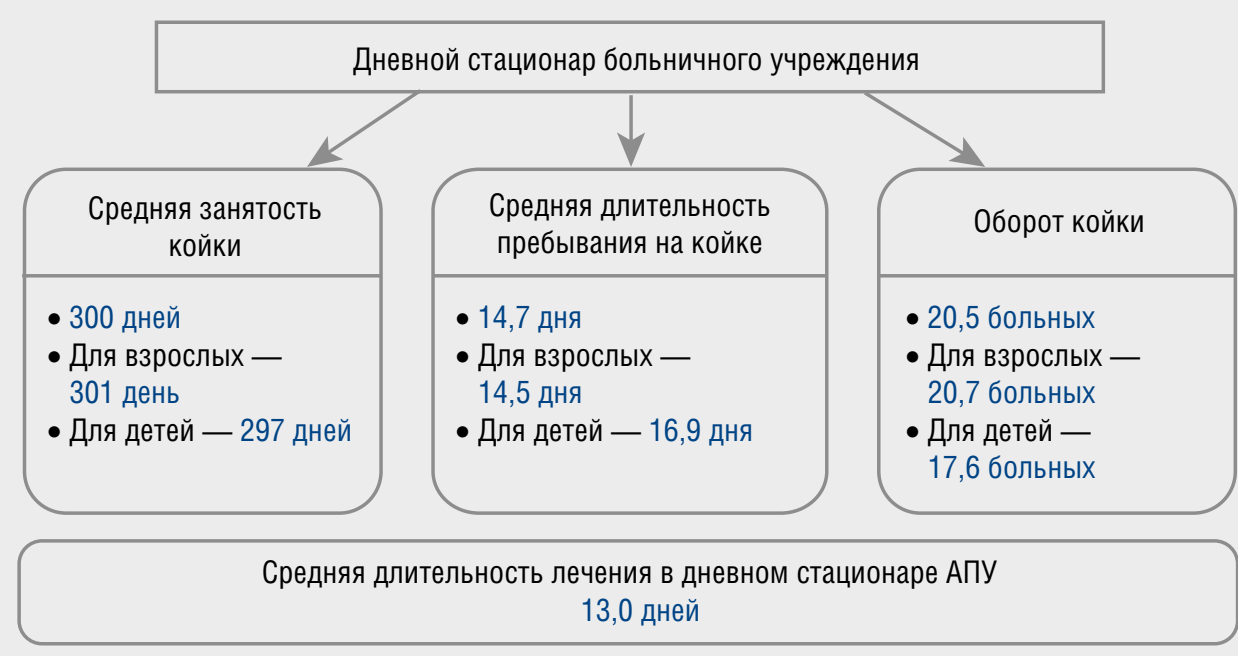

Рис. 8. Работа койки дневного стационара дерматовенерологического профиля в Российской Федерации [2012 год] 


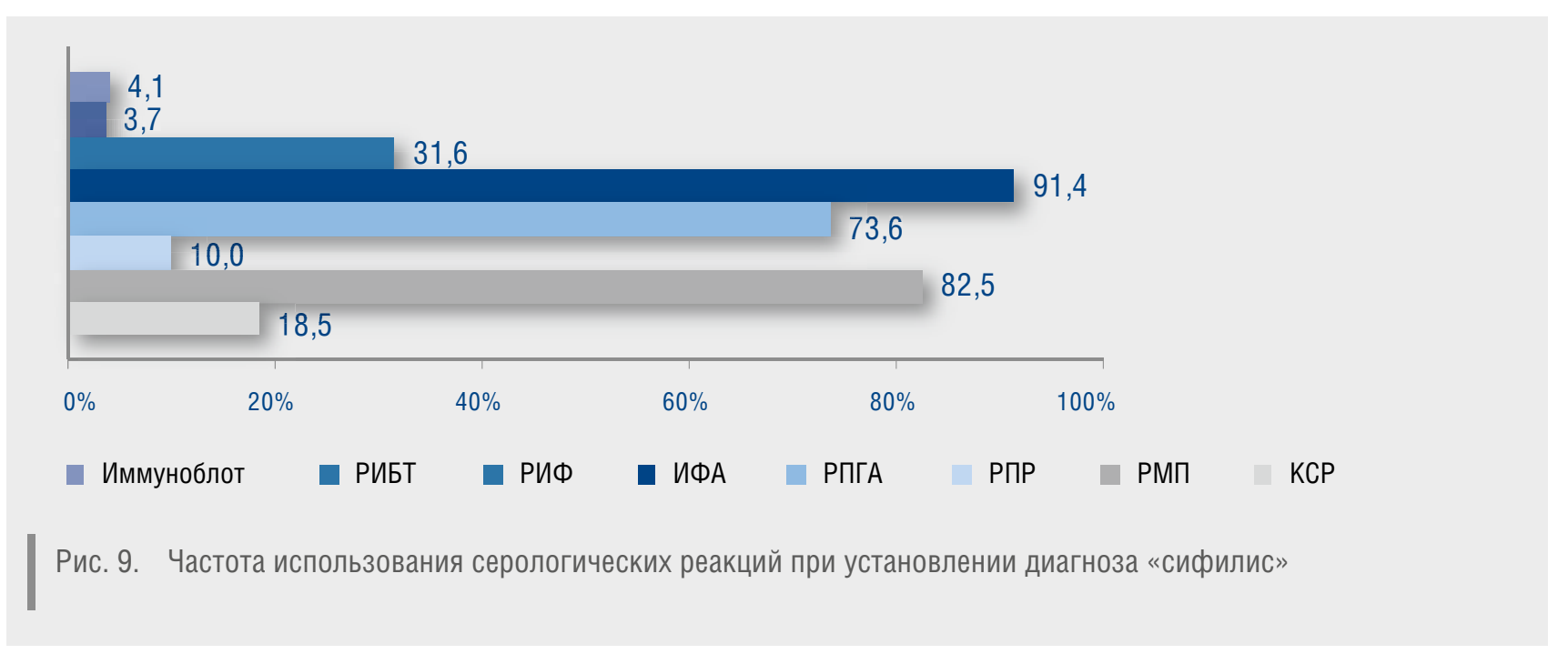

да входят РМП, РСК с кардиолипиновым и РСК с трепонемным антигенами. Данное лабораторное исследование провели у 18,5\% пациентов (рис. 9).

Основными методами лабораторного исследования для подтверждения диагноза «гонококковая инфекция» в 2012 году были бактериоскопический и бактериологический (выполнены у 100,0 и 37,4\% больных соответственно). Диагноз «хламидийная иноекция» у 46\% больных был установлен с учетом результатов исследований методом ИФА, у 18\% - методом прямой иммунофлюоресценции и у 63\% - молекулярно-биологическим. В 100\% случаев микроскопический метод стал основанием для подтверждения диагноза «трихомониаз».

Совершенствование профиллактики является стратегической целью обеспечения национальной безопасности в сорере здравоохранения и здоровья нации [1]. Следует отметить, что значительно улучшилась работа специалистов по выявлению больных сифилисом. Так, по представленным данным фредерального статистического наблюдения в 2012 году специалисты обследовали в 100\% случаев полового партнера (соотношение 1:1; соотношение в 2010 году - 1:0,9). Обследование бытовых контактов больных сифилисом в 2012 году снизилось, соотношение «больной сифилисом : обследованный бытовой контакт» составило 1:1,5 (в 2010 году - 1:1,6).

Активное выявление больных сифилисом специалистами всех профилей составило в 2012 году 77,1\% от общего числа вновь выявленных случаев сифилиса. В медицинских организациях дерматовенерологического профиля было выявлено 23,1\% больных с вновь установленным диагнозом «сифилис», 19,6\% больных было выявлено в других медицинских организациях, 16,8\% - в стационарах всех профилей (рис. 10).

В 2012 году из числа выписанных из стационаров всех профилей пациентов 21322243 были обследо- ваны с применением иммунологических методов исследования с целью выявления пациентов, больных сифилисом, при этом было выявлено 7939 больных с вновь установленным диагнозом «сифилис», что составило 37 больных на 100 тысяч обследованных.

Медицинские осмотры населения регламентируются Приказом Минздравсоцразвития РФ от 12.04.2011 № 302н «Об утверждении перечней вредных и (или) опасных производственных факторов и работ, при выполнении которых проводятся обязательные предварительные и периодические медицинские осмотры (обследования), и Порядка проведения обязательных предварительных и периодических медицинских осмотров (обследований) работников, занятых на тяжелых работах и на работах с вредными и (или) опасными условиями труда».

Выявляемость больных при проведении всех видов медицинских осмотров составила 17,7\%, из них: 8,0\% больных выявлено при профилактических медицинских осмотрах, 5,1\% - при поступлении на работу, 3,4\% - при периодических медицинских осмотрах декретированного контингента и 1,2\% - при обследовании доноров (рис. 10, 11).

Организационно-правовые и лечебно-профилактические мероприятия, проводимые организаторами здравоохранения и специалистами медицинских организаций дерматовенерологического профиля, привели к снижению интенсивных показателей заболеваемости инфекциями, передаваемыми половым путем, и к стабилизации эпидемиологической ситуации среди населения Российской Федерации.

В 2012 году заболеваемость всеми ИППП на территории Российской Федерации составила 267,9 на 100 тысяч населения. Снижение заболеваемости населения ИППП по отношению к 2010 году достигло $21 \%$. В среднем ежегодное снижение заболеваемости за период 2010-2012 гг. составляет 11\% (рис. 12). 


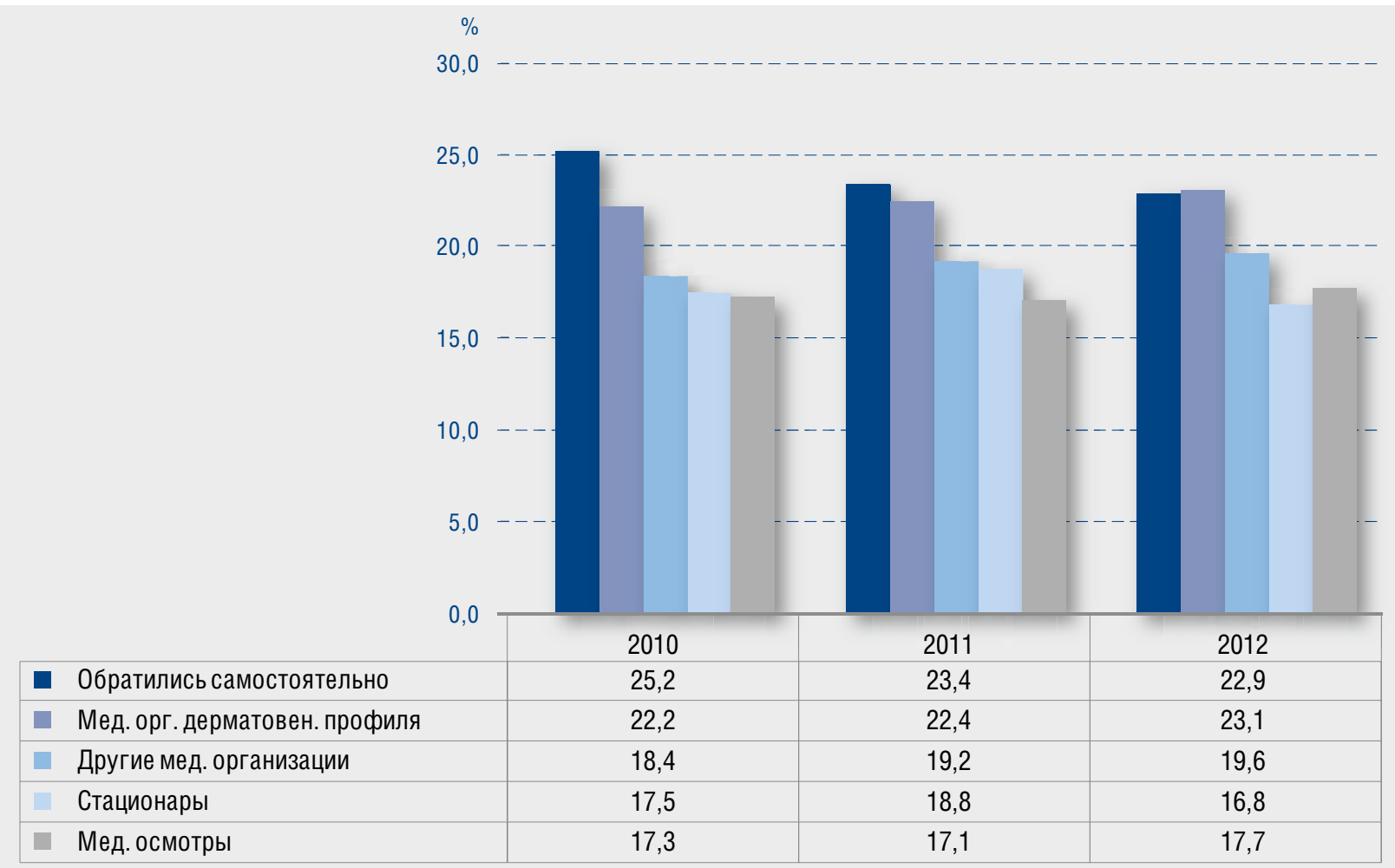

Рис. 10. Выявлено больных сифилисом в Российской Федерации (\%) [2010-2012 гг.]

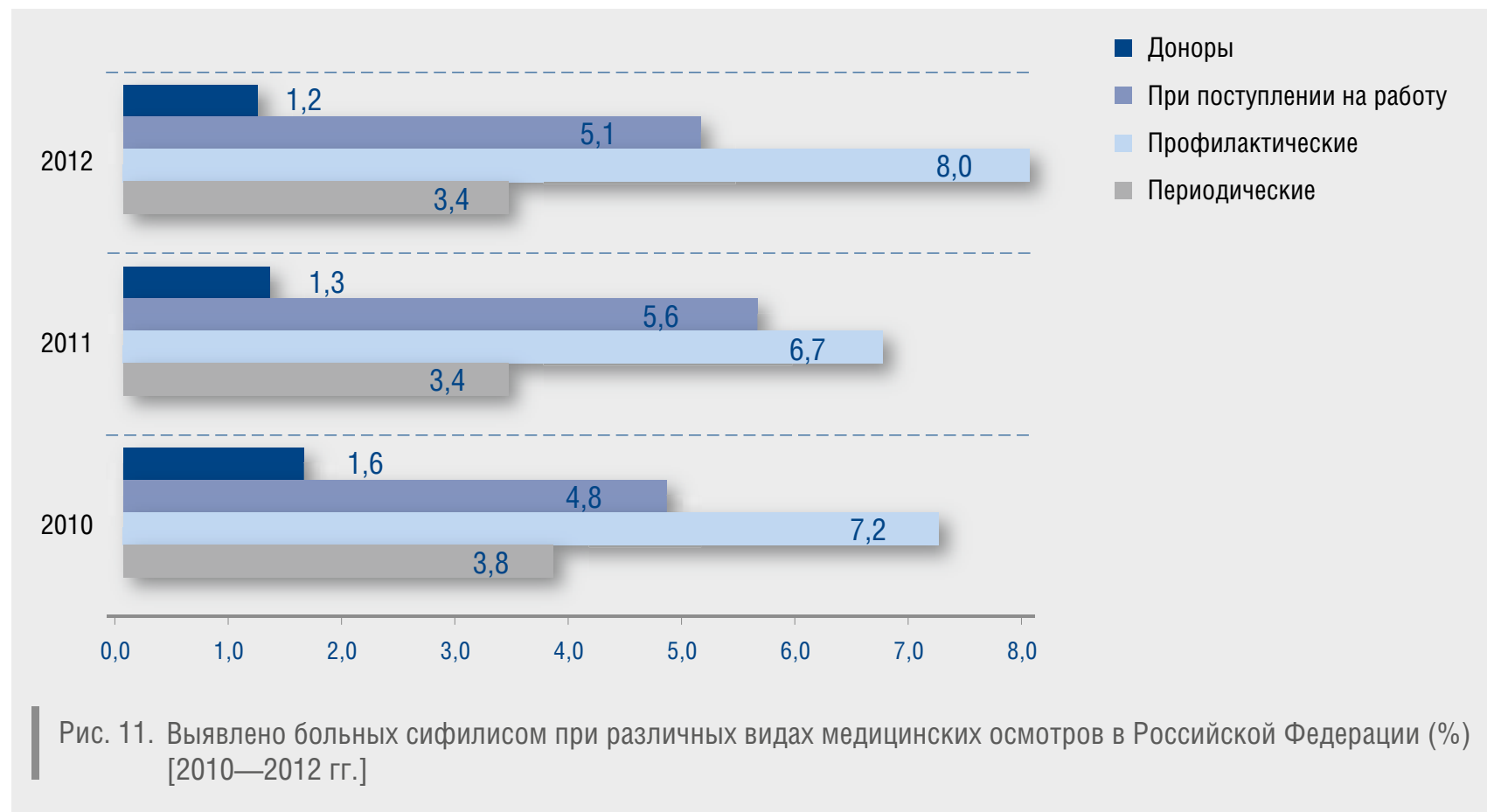


Число зарегистрированных случаев ИППП 382720
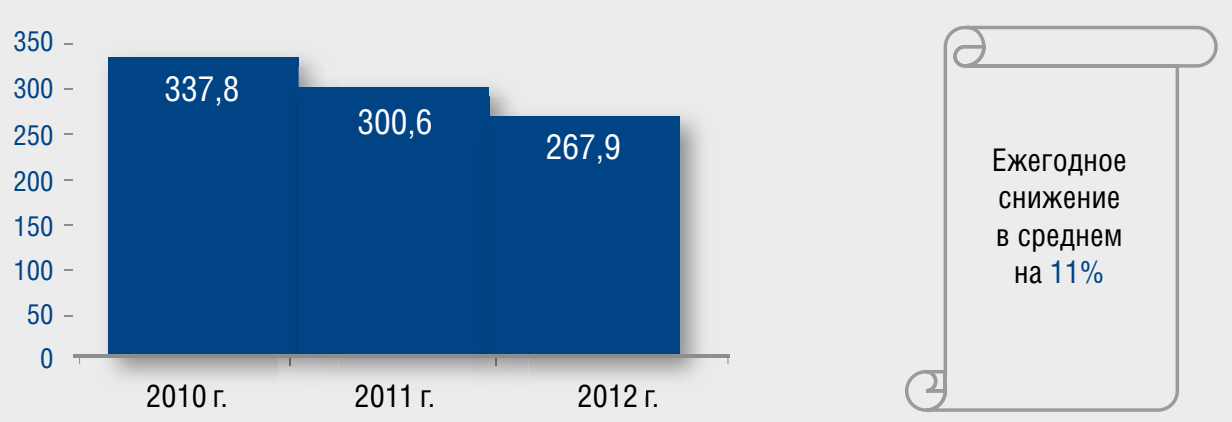

Рис. 12. Заболеваемость всеми ИППП в Российской Федерации (на 100 тыс. населения) [2010-2012 гг.]

Снижение заболеваемости ИППП в федеральных округах Российской Федерации происходит неравномерно. Наибольшее снижение заболеваемости за период 2010-2012 гг. зарегистрировано в Уральском, Южном и Центральном фредеральных округах $(-27,4$, $-27,0$ и -27,5\% соответственно). При этом показатели заболеваемости в Южном и Центральном округах ниже аналогичного среднероссийского показателя (220,6 и 179,2 на 100 тысяч населения соответственно), и только в Уральском федеральном округе заболеваемость всеми ИППП несколько выше среднероссийского показателя заболеваемости. В Сибирском, Дальневосточном и Приволжском федеральных округах, где продолжают регистрироваться наиболее высокие показатели заболеваемости, за период 2010-2012 гг. отмечается самая низкая динамика снижения заболеваемости $(-16,8,-15,0$ и -14,6\% соответственно) по сравнению с аналогичным показателем в целом по Российской Федерации (-20,7\%) (табл. 1).

Одной из наиболее социально опасных инфекций, передаваемых половым путем, является заболевание «сифилис», доля которого в Российской Федерации составляет 12,3\% от всех ИППП. В 2012 году было вновь зарегистрировано 47268 случаев сифилиса, что соответствует 33,1 на 100 тысяч населения и на 25,8\% ниже аналогичного показателя 2010 года (рис. 13).

\section{Таблица 1 Ранговая таблица заболеваемости всеми инфекциями, передаваемыми половым путем, в Российской Федерации [2010-2012 гг.]}

\begin{tabular}{|c|c|c|c|c|c|c|c|c|}
\hline \multirow{2}{*}{$\begin{array}{l}\text { Ранговое } \\
\text { место }\end{array}$} & \multirow[b]{2}{*}{ Наименование субъекта } & \multicolumn{2}{|c|}{2010 г. } & \multicolumn{2}{|c|}{2011 г. } & \multicolumn{2}{|c|}{2012 г. } & \multirow{2}{*}{$\frac{2010 / 2012}{\%}$} \\
\hline & & абс. & $\begin{array}{c}\text { на } 100 \\
\text { тыс. нас. }\end{array}$ & абс. & $\begin{array}{c}\text { на } 100 \\
\text { тыс. нас. }\end{array}$ & абс. & $\begin{array}{c}\text { на } 100 \\
\text { тыс. нас. }\end{array}$ & \\
\hline & Российская Федерация & 479367 & 337,8 & 429469 & 300,6 & 382720 & 267,9 & $-20,7$ \\
\hline 1 & Сибирский Ф0 & 93761 & 479,3 & 84481 & 438,8 & 76815 & 399,0 & $-16,8$ \\
\hline 2 & Дальневосточный Ф0 & 29489 & 457,9 & 27056 & 430,5 & 24469 & 389,3 & $-15,0$ \\
\hline 3 & Уральский Ф0 & 51293 & 417,7 & 41319 & 341,8 & 36677 & 303,4 & $-27,4$ \\
\hline 4 & Приволжский Ф0 & 107834 & 358,1 & 98145 & 328,5 & 91345 & 305,7 & $-14,6$ \\
\hline 5 & Северо-Западный Ф0 & 47761 & 355,5 & 43581 & 319,8 & 39776 & 291,9 & $-17,9$ \\
\hline 6 & Южный Ф0 & 41434 & 302,1 & 35612 & 257,1 & 30556 & 220,6 & $-27,0$ \\
\hline 7 & Центральный Ф0 & 91723 & 247,1 & 85577 & 222,6 & 68886 & 179,2 & $-27,5$ \\
\hline 8 & Северо-Кавказский Ф0 & 16033 & 173,2 & 13698 & 145,1 & 14098 & 149,4 & $-13,7$ \\
\hline
\end{tabular}


Как уже отмечалось выше, наблюдаются позитивные тенденции в складывающейся эпидемиологической ситуации в целом по Российской Федерации, что подтверждается снижением заболеваемости ранними формами сифилиса (на $-31,5 \%$ за три последних года) и увеличением поздних форм сифилиса (+36\% за аналогичный период) (рис. 14). Соотношение клинических форм сифилиса складывается следующим образом: доля первичного сифилиса составляет 14,8\%, доля вторичного сифилиса - 36,3\%, доля раннего скрытого - 45,8\% и 2,8\% приходится на поздние фрормы сифилиса.

Уровень заболеваемости сифилисом в целом по России определяется показателями заболеваемости, регистрируемыми в федеральных округах (табл. 2).

Наиболее высокие показатели заболеваемости сифилисом сохраняются в Сибирском $(63,3)$ и Даль-
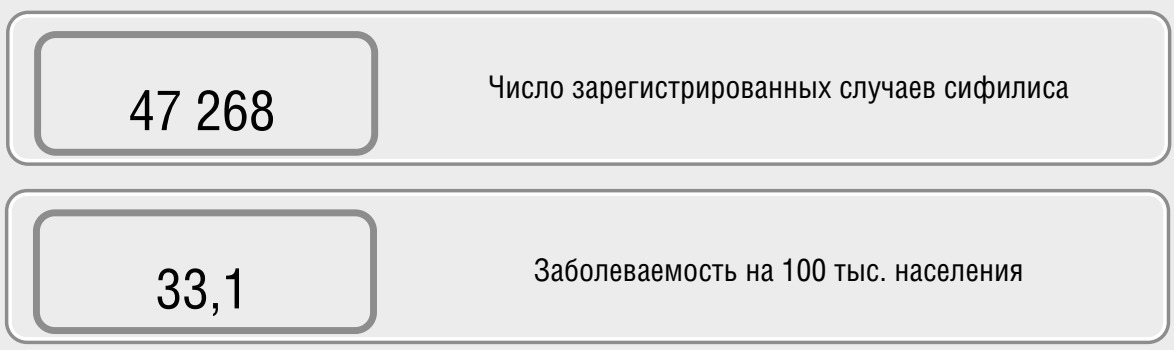

$12,3 \%$

Доля сисиилитической инфекции от всех ИППП

Рис. 13. Заболеваемость сифиилисом в Российской Федерации [2012 г.]

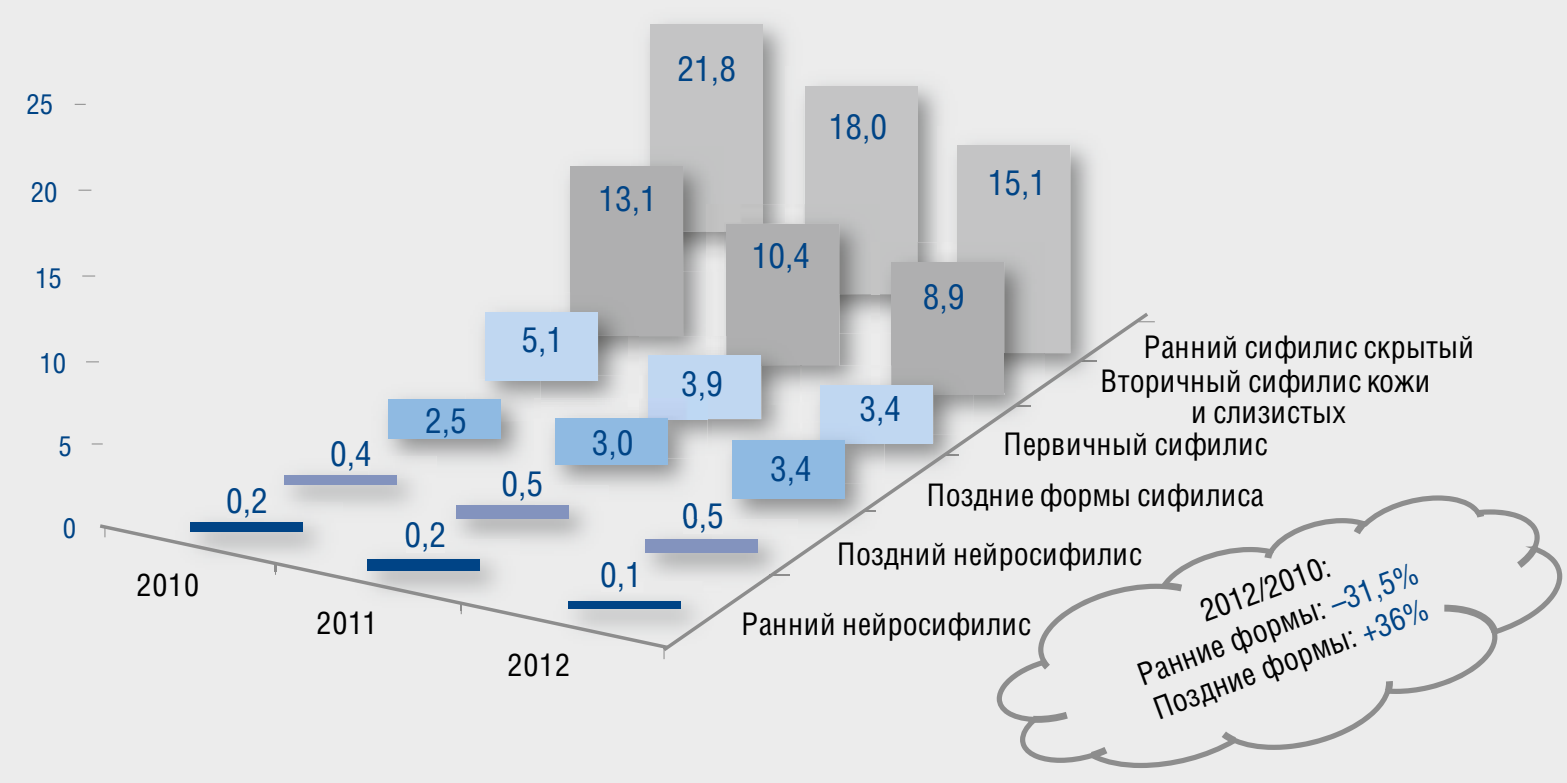

Рис. 14. Динамика заболеваемости различными формами сифилиса в Российской Федерации (на 100 тыс. населения)[2010_2012 гг.] 
Таблица 2 Заболеваемость сифрилисом в фредеральных округах [2010-2012 гг.]

\begin{tabular}{|c|c|c|c|c|c|c|c|}
\hline \multirow{2}{*}{$\begin{array}{l}\text { Ранговое } \\
\text { место }\end{array}$} & \multirow[b]{2}{*}{ Наименование субъекта } & \multicolumn{2}{|c|}{2010 г. } & \multicolumn{2}{|c|}{2011 г. } & \multicolumn{2}{|c|}{2012 г. } \\
\hline & & $\begin{array}{c}\text { абсолютное } \\
\text { число }\end{array}$ & $\begin{array}{c}\text { на } 100 \text { тыс. } \\
\text { нас. }\end{array}$ & $\begin{array}{c}\text { абсолютное } \\
\text { число }\end{array}$ & $\begin{array}{c}\text { на } 100 \text { тыс. } \\
\text { нас. }\end{array}$ & $\begin{array}{c}\text { абсолютное } \\
\text { число }\end{array}$ & $\begin{array}{c}\text { на } 100 \text { тыс. } \\
\text { нас. }\end{array}$ \\
\hline & Российская Федерация & 63707 & 44,9 & 53773 & 37,6 & 47268 & 33,1 \\
\hline 1 & Дальневосточный Ф0 & 5308 & 82,4 & 4629 & 73,7 & 4013 & 63,9 \\
\hline 2 & Сибирский Ф0 & 15801 & 80,8 & 13704 & 71,2 & 12194 & 63,3 \\
\hline 3 & Северо-Западный Ф0 & 6204 & 46,2 & 5331 & 39,1 & 5133 & 37,7 \\
\hline 4 & Приволжский Ф0 & 13452 & 44,7 & 11626 & 38,9 & 9707 & 32,5 \\
\hline 5 & Уральский Ф0 & 5197 & 42,3 & 4252 & 35,2 & 3324 & 27,5 \\
\hline 6 & Центральный Ф0 & 11693 & 31,5 & 9493 & 24,7 & 8412 & 21,9 \\
\hline 7 & Южный Ф0 & 4286 & 31,3 & 3290 & 23,8 & 3201 & 23,1 \\
\hline 8 & Северо-Кавказский Ф0 & 1766 & 19,1 & 1448 & 15,3 & 1284 & 13,6 \\
\hline
\end{tabular}

невосточном $(63,9)$ федеральных округах, в которых заболеваемость сифилисом превышает среднероссийский показатель в два раза. Высокий уровень заболеваемости в Сибирском фредеральном округе обусловлен в том числе сверхвысокими показателями в Республике Тыва. Например, 1970-е годы для Республики Тыва были особенно благоприятны. Показатели заболеваемости сифилисом на ее территории были в 2,5 раза ниже среднеросийских показателей. Однако начиная с 1980-х годов интенсивность распространения сифилиса на данной территории резко увеличилась, уровень заболеваемости вырос в несколько раз и по настоящее время остается самым высоким среди всех субъектов Российской Федерации, превышая среднероссийский показатель в 5,5 раза.

Признать в некоторых субъектах показатели заболеваемости сифилисом ниже среднероссийских как состояние эпидемиологического благополучия не представляется возможным, ввиду того что отмечается тенденция в обращении за медицинской помощью части пациентов в коммерческие медицинские организации, не имеющие надлежащего статистического учета и находящихся как в самом субъекте, так и в других фредеральных округах. Наряду с этим имеют место случаи обращений пациентов после самолечения, после неполноценного лечения у специалистов других профилей, которые, как правило, не подают сведения о таких больных, что, соответственно, ведет к недоучету числа случаев заболеваний и к искажению истинной заболеваемости.

Заболеваемость сифилисом взрослого населения к 2012 году сократилась в 3,7 раза. Интенсивность снижения заболеваемости взрослого населения за период 2002-2012 гг. была неоднозначной. С 2002 по 2005 г. среднее снижение заболеваемости за год происходило на 14,7\%. В последующие 2006-2008 гг. интенсивность снижения заболеваемости резко сократилась в 3,4 раза и составила в среднем 4,3\% за год. Начиная с 2009 года и по 2012 год интенсивность снижения заболеваемости сифилисом увеличилась и в среднем составила 13,6\% за год (рис. 15).

Заболеваемость сифилисом детей в возрасте 1517 лет за аналогичный период снизилась в 5,2 раза. Интенсивность снижения заболеваемости сифилисом среди детей 15-17 лет была в полтора раза выше, чем у взрослых, и составляла в среднем 14,4\%. Наиболее выраженный процент снижения отмечался в 2009-2012 гг., который варьировал от 10,6 до 27,7\%, составляя в среднем $17,8 \%$.

Эффрективное выполнение мероприятий, проводимых в рамках подпрограммы «Инфекции, передаваемые половым путем» Федеральной целевой программы «Предупреждение и борьба с социально значимыми заболеваниями (2007-2011 годы)», способствовало снижению заболеваемости сифилисом среди всего населения. Организация центров «Доверие» для оказания специализированной помощи детям и подросткам в 45 субъектах Российской Федерации и организационно-профилактические мероприятия (создание специализированных сайтов, размещение информационно-просветительных материалов в средствах массовой информации) значительно снизили распространение инфекций, передаваемых половым путем, среди взрослого и подросткового населения.

Среди урогенитальных инфекций трихомониаз имеет наиболее высокий показатель заболеваемости, составляющий 94,1 на 100 тысяч населения в целом по Российской Федерации, заболеваемость урогени- 


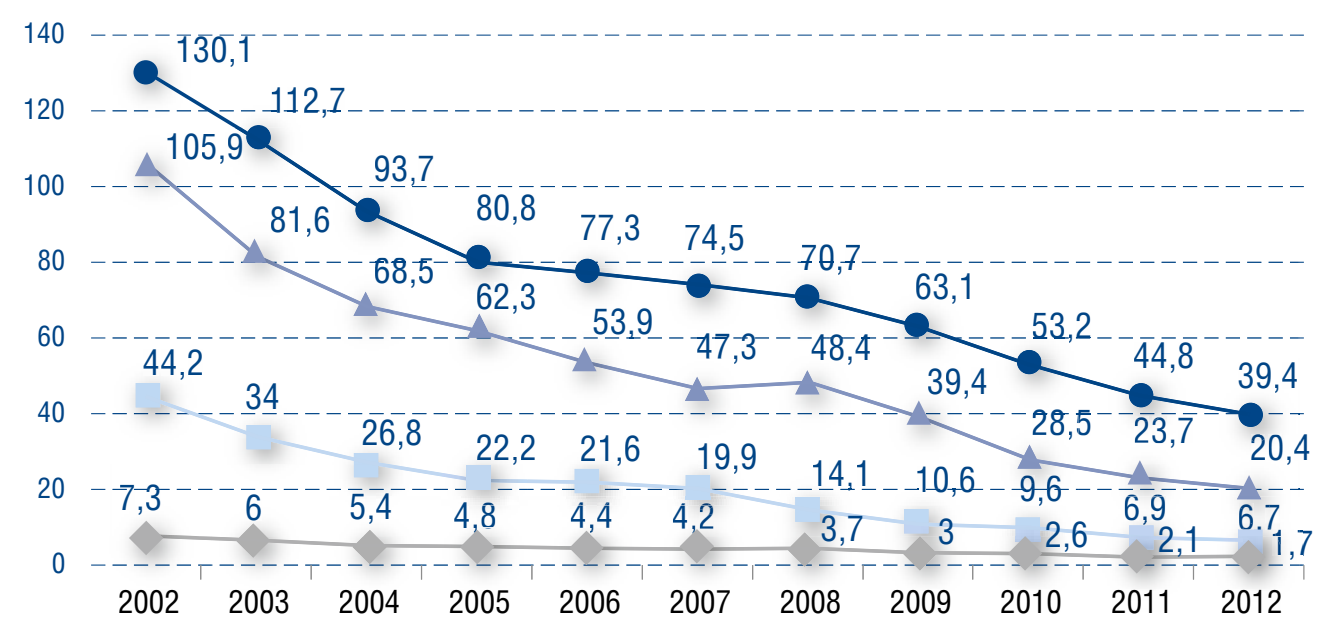

Врожденный сифилис (на 100 тыс. живорожд.)

Дети 0-14 лет (на 100 тыс. соотв. населения)

- Дети 15-17 лет (на 100 тыс. соотв. населения)

Рис. 15. Динамика заболеваемости сисрилисом по возрастным категориям в Российской Федерации (на 100 тыс. соотв. населения) [2002-2012 гг.]

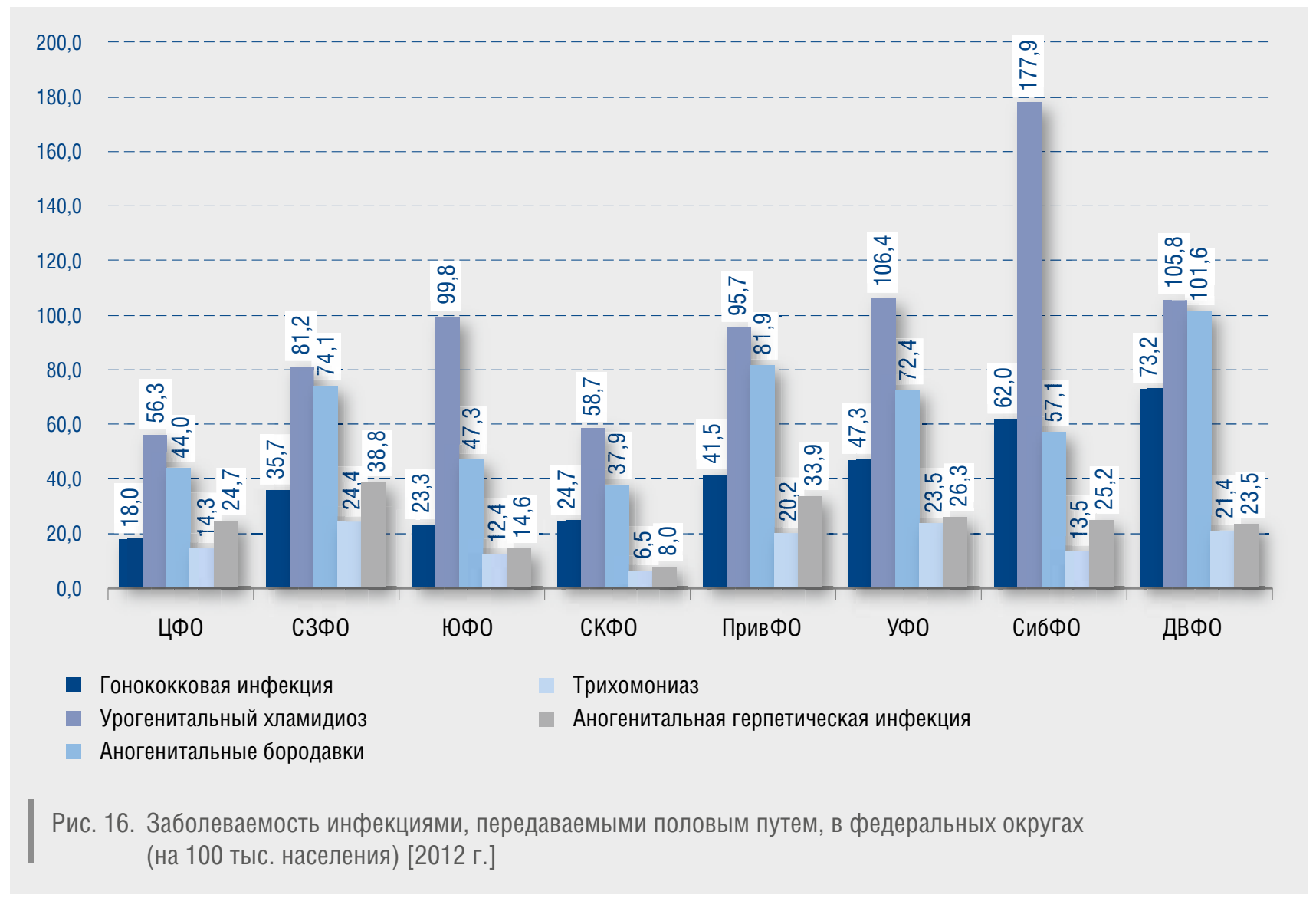


Таблица 3 Заболеваемость гонококковой, хламидийной инфекцией и трихомониазом в Российской Федерации (на 100 тыс. населения) [2011-2012 гг.]

\begin{tabular}{lccccccccc}
\hline \multirow{2}{*}{$\begin{array}{l}\text { Наименование } \\
\text { федерального округа }\end{array}$} & \multicolumn{3}{c}{ Гонококковая инсекция } & \multicolumn{3}{c}{ Трихомониаз } & \multicolumn{3}{c}{ Хламидийная инсекция } \\
\cline { 2 - 12 } & 2011 & 2012 & $\begin{array}{c}2012 / 2011 \\
(\%)\end{array}$ & 2011 & 2012 & $\begin{array}{c}2012 / 2011 \\
(\%)\end{array}$ & 2011 & 2012 & $\begin{array}{c}2012 / 2011 \\
(\%)\end{array}$ \\
\hline Российская Федерация & 38,2 & 36,4 & $-4,7 \%$ & 111,4 & 94,1 & $-15,5 \%$ & 65,9 & 61,4 & $-6,8 \%$ \\
\hline Центральный & 19,9 & 18,0 & $-9,5 \%$ & 74,0 & 56,3 & $-23,9 \%$ & 53,1 & 44,0 & $-17,1 \%$ \\
\hline Северо-Западный & 35,4 & 35,7 & $0,8 \%$ & 100,7 & 81,2 & $-19,4 \%$ & 79,0 & 74,1 & $-6,2 \%$ \\
\hline Южный & 24,1 & 23,3 & $-3,3 \%$ & 121,0 & 99,8 & $-17,5 \%$ & 55,0 & 47,3 & $-14,0 \%$ \\
\hline Северо-Кавказский & 24,8 & 24,7 & $-0,4 \%$ & 60,0 & 58,7 & $-2,2 \%$ & 31,6 & 37,9 & $19,9 \%$ \\
\hline Приволжский & 42,4 & 41,5 & $-2,1 \%$ & 108,9 & 95,7 & $-12,1 \%$ & 82,1 & 81,9 & $-0,2 \%$ \\
\hline Уральский & 48,3 & 47,3 & $-2,1 \%$ & 124,1 & 106,4 & $-14,3 \%$ & 80,5 & 72,4 & $-10,1 \%$ \\
\hline Сибирский & 66,3 & 62,0 & $-6,5 \%$ & 203,5 & 177,9 & $-12,6 \%$ & 59,6 & 57,1 & $-4,2 \%$ \\
\hline Дальневосточный & 81,6 & 73,2 & $-10,3 \%$ & 125,7 & 105,8 & $-15,8 \%$ & 105,2 & 101,6 & $-3,4 \%$ \\
\hline
\end{tabular}

Таблица 4

Заболеваемость аногенитальной герпетической инфекцией и аногенитальными (венерическими) бородавками в Российской Федерации (на 100 тыс. населения) [2011-2012 гг.]

\begin{tabular}{lcccccc}
\hline \multirow{2}{*}{$\begin{array}{l}\text { Наименование федерального } \\
\text { округа }\end{array}$} & \multicolumn{2}{c}{ Аногенитальная герпетическая инфекция } & \multicolumn{2}{c}{ Аногенитальные (венерические) бородавки } \\
\cline { 2 - 7 } & 2011 & 2012 & $2012 / 2011(\%)$ & 2011 & 2012 & $2012 / 2011(\%)$ \\
\hline Российская Федерация & 18,3 & 16,8 & $-8,2 \%$ & 29,2 & 26,0 & $-11,0 \%$ \\
\hline Центральный & 19,7 & 14,3 & $-27,4 \%$ & 31,2 & 24,7 & $-20,8 \%$ \\
\hline Северо-Западный & 26,9 & 24,4 & $-9,3 \%$ & 38,8 & 38,8 & $0,0 \%$ \\
\hline Южный & 15,8 & 12,4 & $-21,5 \%$ & 17,5 & 14,6 & $+16,6 \%$ \\
\hline Северо-Кавказский & 7,8 & 6,5 & $+16,7 \%$ & 5,5 & 8,0 & $+45,5 \%$ \\
\hline Приволжский & 18,4 & 20,2 & $++9,8 \%$ & 37,7 & 33,9 & $-10,1 \%$ \\
\hline Уральский & 25,0 & 23,5 & $-6,0 \%$ & 28,9 & 26,3 & $-9,0 \%$ \\
\hline Сибирский & 12,3 & 13,5 & $+9,8 \%$ & 25,9 & 25,2 & $-2,7 \%$ \\
\hline Дальневосточный & 16,3 & 21,4 & $+31,3 \%$ & 27,7 & 23,5 & $-15,2 \%$
\end{tabular}

таным хламидиозом составляет 61,4, заболеваемость гонококковой инфекцией - 36,4 на 100 тысяч населения (рис.16, табл. 3, 4).

Заболеваемость вирусными иноекциями, передаваемыми половым путем, в 2012 году в целом по Российской Федерации имеет тенденцию к снижению по сравнению с предыдущим годом. В Центральном, Северо-Западном, Южном и Уральском федеральных округах тенденция заболеваемости аногенитальной герпетической инфекцией в целом аналогична тенденции по Российской Федерации. На фоне этого в остальных федеральных округах отмечается рост заболеваемости в среднем на 18,6\%. Следует отметить, что выраженный рост заболеваемости аногени- тальными (венерическими) бородавками отмечается только в Южном и Северо-Кавказском фредеральных округах (табл. 4).

Большая часть деятельности специалистов медицинских организаций дерматовенерологического профриля направлена на оказание медицинской помощи пациентам с болезнями кожи и подкожной клетчатки.

В Российской Федерации распространенность болезней кожи и подкожной клетчатки в 2012 году была на уровне 6221,3, а заболеваемость - 4813,1 на 100 тысяч населения (рис. 17).

Доля часто встречающихся дерматозов (атопический дерматит, псориаз, артропатический псориаз, контактный дерматит, другие дерматиты (экзема), диско- 


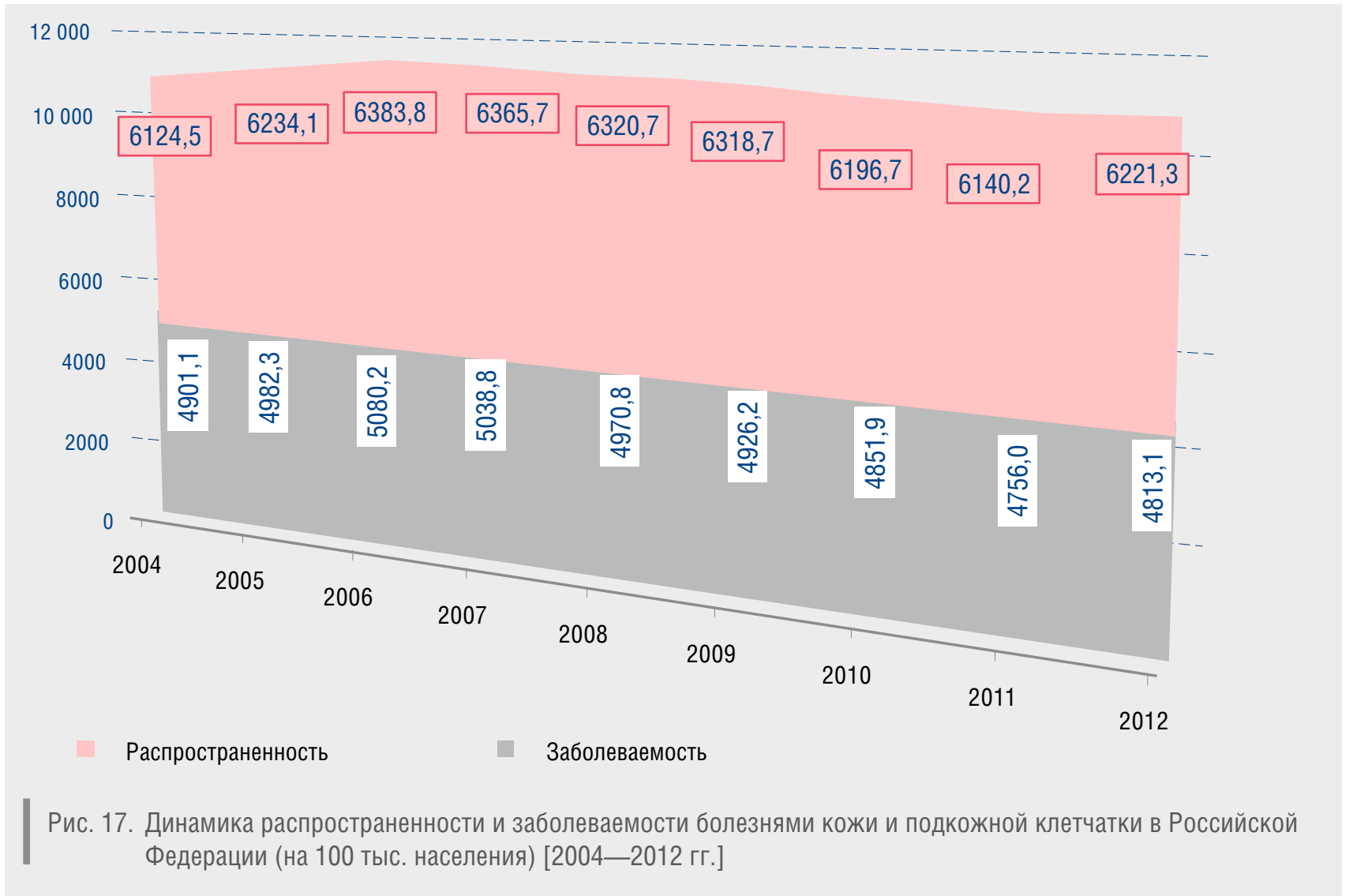

идная красная волчанка (ДКВ), локализованная склеродермия) в структуре распространенности всех болезней кожи и подкожной клетчатки составляет $38,1 \%$.

Распространенность контактного дерматита среди вышеуказанных нозологий достигает 52,9\%, атопического дерматита - 19,1\%, других дерматитов (экземы) - 17,4\%, псориаза - 9,4\%, артропатического псориаза и склеродермии - по 0,5\%, ДКВ - 0,2\%. Структура заболеваемости данными дерматозами в целом соответствует структуре их распространенности среди всего населения Российской Федерации в 2012 году (рис. 18).

Чаще всего болезнями кожи и подкожной клетчатки страдают дети в возрасте 0-17 лет. Заболеваемость в данной возрастной категории почти в три раза превышает аналогичный показатель взрослого населения. В детской возрастной группе 0-17 лет показатель заболеваемости болезнями кожи и подкожной клетчатки у детей 0-14 лет на 11,7\% выше, чем в подростковой группе детей 15-17 лет, составляя соответственно 9278,7 и 8188,1 на 100 тысяч соответствующего населения. Показатель заболеваемости взрослого населения в 2012 году составил 3849,8 на 100 тысяч соответствующего населения (рис. 19).
В Северо-Западном, Уральском, Сибирском, Приволжском и Дальневосточном федеральных округах в 2012 году регистрируются наиболее высокие показатели заболеваемости атопическим дерматитом и псориазом, которые превышают среднероссийские показатели (табл. 5).

Заболеваемость дискоидной красной волчанкой и локализованной склеродермией в целом сохраняется на уровне предыдущих лет. Однако в ряде округов показатели заболеваемости данными патологиями увеличились по сравнению с 2011 годом: прирост заболеваемости ДКВ в Центральном федеральном округе составил $+80 \%$, прирост заболеваемости ДКВ в Уральском федеральном округе +25\%; прирост заболеваемости локализованной склеродермией в Южном федеральном округе составил $+44 \%$ (табл. 6).

В соответствии с Порядком оказания медицинской помощи населению по профилю “дерматовенерология», утвержденным Приказом Минздрава России от 15.11.2012 № 924н, медицинские организации дерматовенерологического профиля (диспансеры) должны осуществлять диспансерное наблюдение больных болезнями кожи и подкожной клетчатки. 


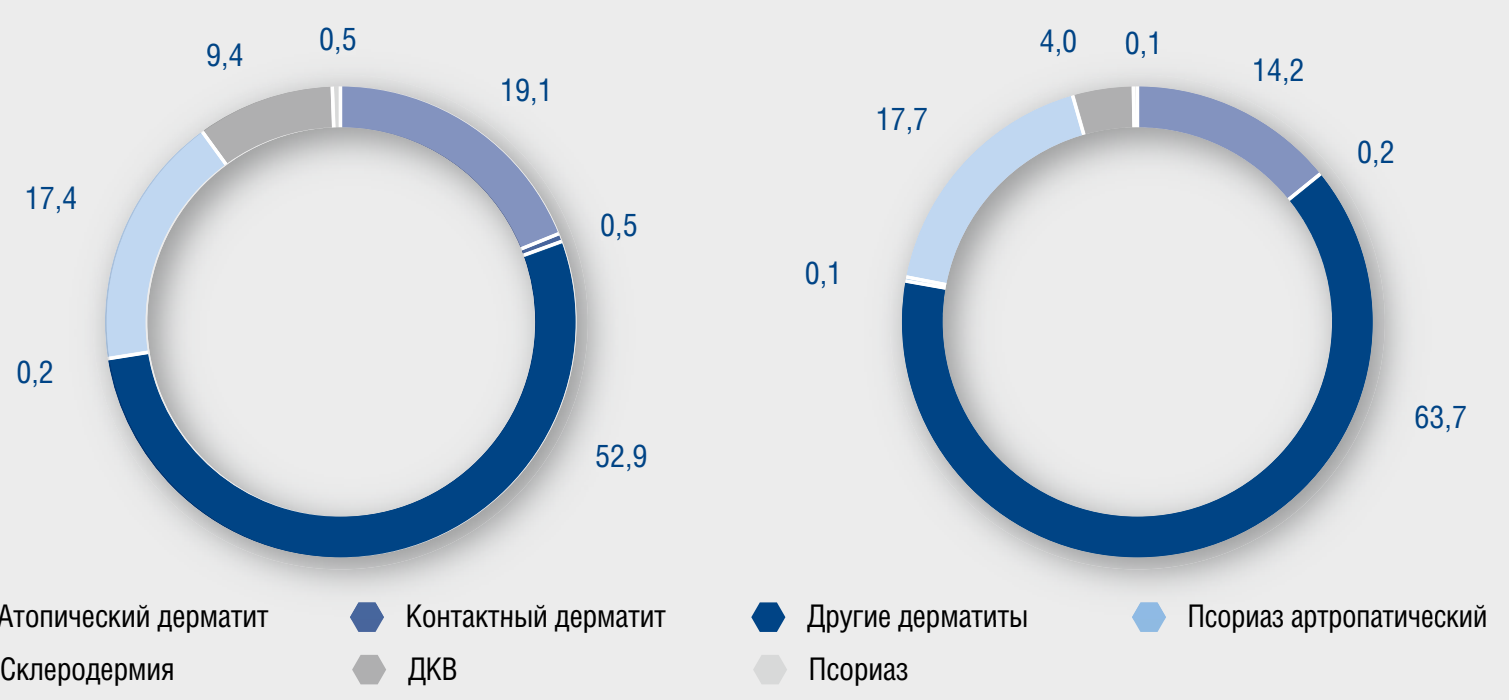

Рис. 18. Структура наиболее распространенных дерматозов среди населения Российской Федерации (\%) [2012 г.]

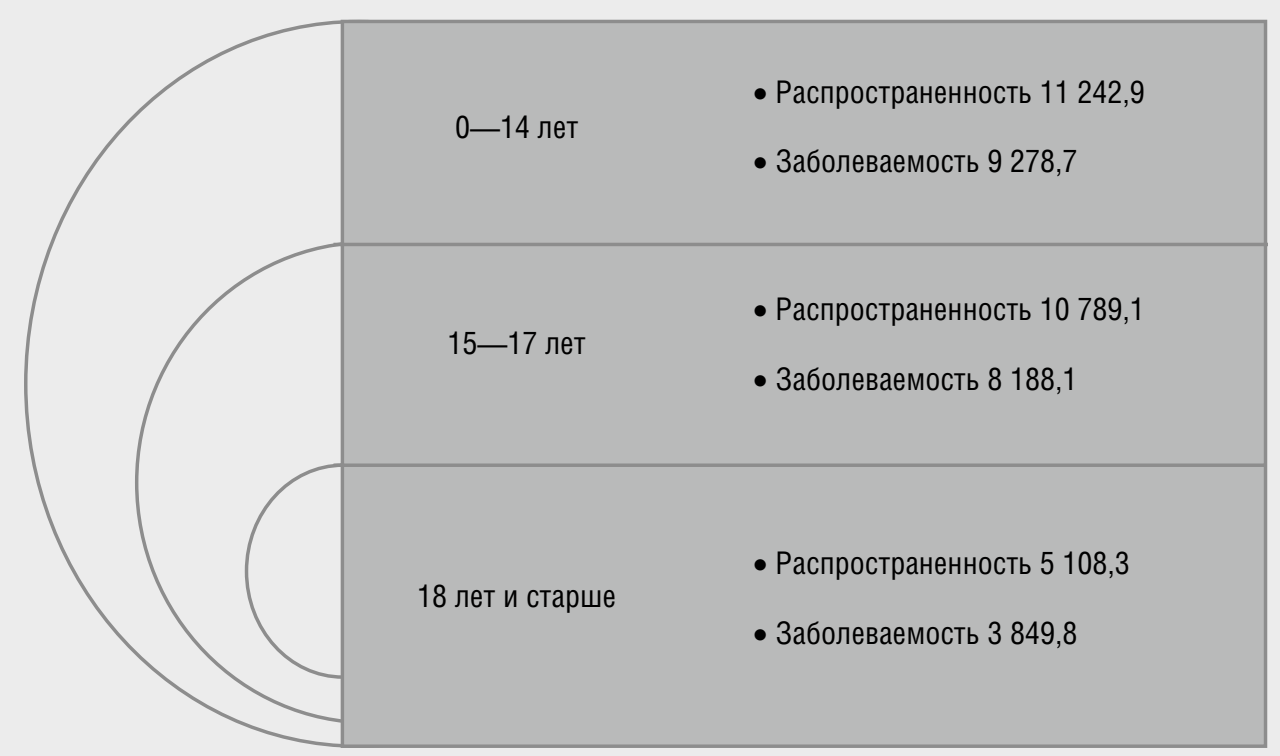

Рис. 19. Повозрастная структура распространенности и заболеваемости болезнями кожи и подкожной клетчатки (на 100 тыс. населения) [2012 г.]

Работа специалистов медицинских организаций дерматовенерологического профиля по охвату больных хроническими дерматозами диспансерным наблюдением остается недостаточной, составляя в среднем $50 \%$ от числа всех больных, обратившихся за медицинской помощью по данным забо- леваниям. Так, в 2012 году в Российской Федерации охват диспансерным наблюдением больных атопическим дерматитом составляет 36,5\%, псориазом - 56,8\%, артропатическим псориазом $70,5 \%$, ДКВ - 73,8\%, локализованной склеродермией $-72,0 \%$ (рис. 20). 
Таблица 5 Заболеваемость атопическим дерматитом и псориазом в Российской Федерации (на 100 тыс. населения)[2011-2012 гг.]

\begin{tabular}{|c|c|c|c|c|c|c|c|c|c|}
\hline \multirow{2}{*}{$\begin{array}{l}\text { Наименование } \\
\text { федерального округа }\end{array}$} & \multicolumn{3}{|c|}{ Атопический дерматит } & \multicolumn{3}{|c|}{ Псориаз } & \multicolumn{3}{|c|}{ Артропатический псориаз } \\
\hline & 2011 & 2012 & $2012 / 2011(\%)$ & 2011 & 2012 & $2012 / 2011(\%)$ & 2011 & 2012 & $2012 / 2011(\%)$ \\
\hline Российская Федерация & 241,8 & 244,5 & $+1,1 \%$ & 69,6 & 68,5 & $-1,6 \%$ & 1,8 & 1,8 & $0,0 \%$ \\
\hline Центральный & 194,8 & 196,7 & $+1,0 \%$ & 65,2 & 62,3 & $-4,4 \%$ & 1,8 & 1,8 & $0,0 \%$ \\
\hline Северо-Западный & 286,6 & 302,1 & $+5,4 \%$ & 75,3 & 74,4 & $-1,2 \%$ & 1,8 & 1,5 & $-16,7 \%$ \\
\hline Южный & 160,4 & 195,6 & $+21,9 \%$ & 40,6 & 44,1 & $+8,6 \%$ & 1,1 & 1,4 & $+27,3 \%$ \\
\hline Северо-Кавказский & 160,1 & 153,0 & $-4,4 \%$ & 51,5 & 51,1 & $-0,8 \%$ & 5,1 & 6,4 & $+25,5 \%$ \\
\hline Приволжский & 305,7 & 304,6 & $-0,4 \%$ & 84,1 & 78,3 & $-6,9 \%$ & 1,5 & 1,5 & $0,0 \%$ \\
\hline Уральский & 254,7 & 239,4 & $-6,0 \%$ & 79,2 & 90,0 & $+13,6 \%$ & 1,5 & 0,9 & $-40,0 \%$ \\
\hline Сибирский & 273,6 & 271,4 & $-0,8 \%$ & 70,9 & 70,2 & $-1,0 \%$ & 1,0 & 1,2 & $+20,0 \%$ \\
\hline Дальневосточный & 304,5 & 305,0 & $+0,2 \%$ & 81,3 & 78,7 & $-3,2 \%$ & 1,4 & 1,9 & $+35,7 \%$ \\
\hline
\end{tabular}

Таблица 6 Заболеваемость дискоидной красной волчанкой и локализованной склеродермией в Российской Федерации (на 100 тыс. населения) [2011-2012 гг.]

\begin{tabular}{lcccccc}
\hline Наименование & \multicolumn{3}{c}{ ДКВ } & \multicolumn{3}{c}{ Локализованная склеродермия } \\
\cline { 2 - 7 } федерального округа & 2011 & 2012 & $2012 / 2011(\%)$ & 2011 & 2012 & $2012 / 2011(\%)$ \\
\hline Российская Федерация & 1,1 & 1,0 & $-9,1 \%$ & 3,4 & 3,3 & $-2,9 \%$ \\
\hline Центральный & 1,0 & 1,8 & $+80,0 \%$ & 2,6 & 3,2 & $+23,1 \%$ \\
\hline Северо-Западный & 0,9 & 1,0 & $+11,1 \%$ & 3,7 & 4,0 & $+8,1 \%$ \\
\hline Южный & 1,2 & 1,2 & $0,0 \%$ & 2,5 & 3,6 & $+44,0 \%$ \\
\hline Северо-Кавказский & 0,7 & 0,8 & $+14,3 \%$ & 1,2 & 1,4 & $+16,7 \%$ \\
\hline Приволжский & 1,3 & 1,2 & $-7,7 \%$ & 5,2 & 4,1 & $-21,2 \%$ \\
\hline Уральский & 0,8 & 1,0 & $+25,0 \%$ & 3,9 & 2,4 & $-38,5 \%$ \\
\hline Сибирский & 1,5 & 1,2 & $-20,0 \%$ & 3,4 & 3,3 & $-2,9 \%$ \\
\hline Дальневосточный & 1,4 & 1,5 & $+7,1 \%$ & 2,7 & 2,6 & $-3,7 \%$
\end{tabular}
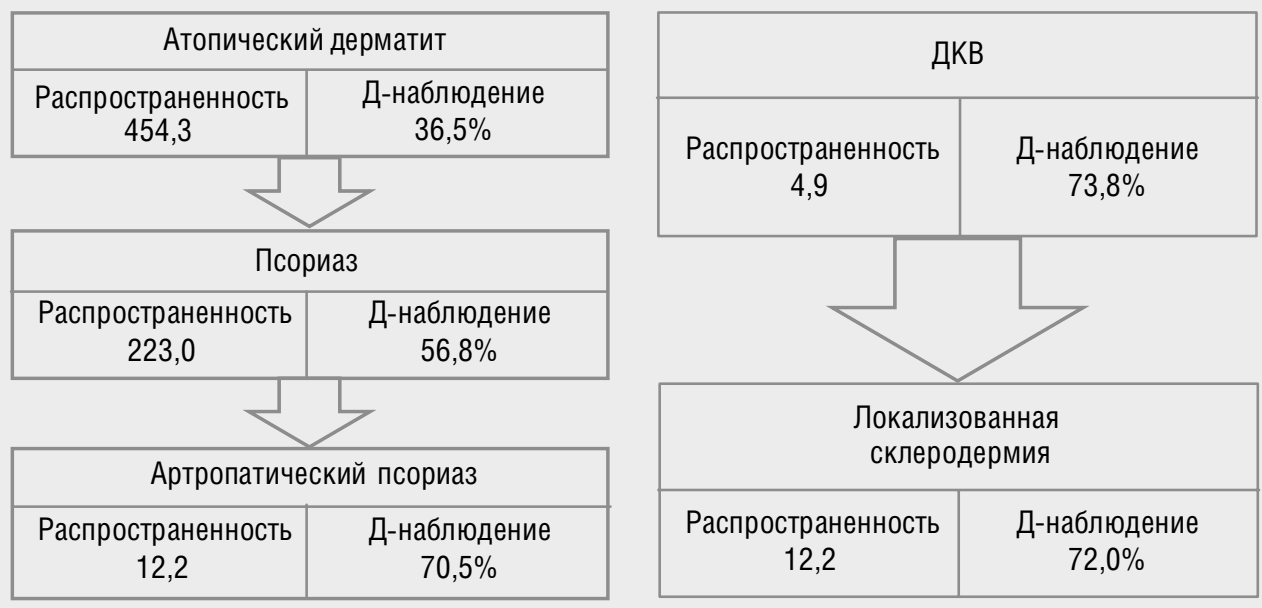

Рис. 20. Распространенность болезней кожи и охват больных диспансерным наблюдением (на 100 тыс. населения, \%) 
Таким образом, проведенный анализ деятельности медицинских организаций дерматовенерологического профриля на основании данных отчетных фрорм федерального статистического наблюдения показал, что проводимые мероприятия по реорганизации способствовали интенсификации и оптимизации работы дерматовенерологической койки, при этом сокращение коечного фонда не повлияло на обеспеченность населения профильными койками. Улучшилась в целом обеспеченность населения Российской Федерации врачами-дерматовенерологами, однако дефицит врачей-специалистов в стране определяется на уровне $9 \%$ в основном за счет учреждений в сельской местности.

В Российской Федерации продолжает сохраняться благоприятная тенденция к снижению заболеваемости инфекциями, передаваемыми половым путем, и уменьшению их распространения среди населения.
На фроне высокой распространенности болезней кожи и подкожной клетчатки среди населения Российской Федерации, особенно в детской возрастной группе 0-17 лет, организация профилактической работы врачей, направленная на стабилизацию процесса, достижения ремиссии заболевания, предупреждение его прогрессирования и развития осложнений, остается на недостаточном уровне. Низкий охват диспансерным наблюдением больных дерматозами требует усиления работы в данном направлении.

В рамках мероприятий, направленных на повышение качества оказания медицинской помощи, специалистами профильной комиссии по дерматовенерологии проведена работа по актуализации стандартов оказания медицинской помощи больным болезнями кожи и инфекциями, передаваемыми половым путем, и Порядка оказания медицинской помощи населению по профилю «дерматовенерология». І I

\section{Литература}

1. Указ Президента РФ от 12.05.2009 № 537 «0 Стратегии национальной безопасности Российской Федерации до 2020 года» (раздел 6. Здравоохранение, пп. 71, 72, 74, 76, 78).

2. Распоряжение Правительства РФ от 24.12.2012 № 2511-р «0б утверждении государственной программы Российской Федерации «Развитие здравоохранения».

3. Федеральный закон от 21.11.2011 № 323-Ф3 (ред. от 25.06.2012) «0б основах охраны здоровья граждан в Российской Федерации».

4. Приказ Минздрава России от 15.11.2012 № 924н «0б утверждении Порядка оказания медицинской помощи населению по просилю «дерматовенерология» (зарегистрирован в Минюсте России 21.12.2012 № 26302).
5. Постановление Правительства РФ от 04.10.2012 № 1006 «0б утверждении Правил предоставления медицинскими организациями платных медицинских услуг».

6. Постановление Правительства РФ от 22.10.2012 № 1074 «0 программе государственных гарантий бесплатного оказания гражданам медицинской помощи на 2013 год и на плановый период 2014 и 2015 годов».

7. Ресурсы и деятельность медицинских организаций дерматовенерологического профиля. Заболеваемость инфекциями, передаваемыми половым путем, заразными кожными болезнями и болезнями кожи за 2010-2011 годы [Статистические материалы]. Москва. 2012. $236 \mathrm{c.}$
8. Отчетная форма федерального статистического наблюдения № 14ДС «Сведения о деятельности дневных стационаров лечебно-профилактического учреждения за 2012 год».

9. Отчетная форма федерального статистического наблюдения № 17 «Сведения о медицинских и фрармацевтических работниках за 2012 год».

10. Отчетная форма федерального статистического наблюдения № 30 «Сведения о медицинской организации за 2012 год».

11. Отчетная форма федерального статистического наблюдения № 47 «Сведения о сети и деятельности медицинских организаций за 2012 ГОД».

об авторах:

А.А. Кубанова — д.м.Н., профессор, академик РАМН, директор ФГБУ «ГНЦДК» Минздрава России, Москва

А.А. Кубанов - д.м.н., профессор, заместитель директора по научной работе ФГБУ «ГНЦДК» Минздрава России, Москва

Л.Е. Мелехина — старший научный сотрудник научно-организационного отдела ФГБУ «ГНЦДК» Минздрава России, Москва

Е.В. Богданова — к.м.Н., старший научный сотрудник научно-организационного отдела ФГБУ «ГНЦДК» Минздрава России, Москва

М.М. Бутарева — к.м.Н., заведующий отделением клинической дерматологии ФГБУ «ГНЦДК» Минздрава России, Москва 